\title{
FUNDAMENTAL STUDIES ON VISCOELASTICITY OF POLYMETHYL METHACRYLATE POLYMERIZED BY MONOMER-POLYMER TECHNIQUE
}

By

Katsuichiro INOUE

Department of Dental Physicotechnology (Director: Prof. Ichiro HAYASHI)

Kyushu Dental College, Kitakyushu, Japan

(Received Jan. 28, 1972)

モノマー・ポリマー重合法によるポリメタクリル酸メチルの粘弾性に関する 基 礎 的研 究

䨑科理工学教室 (指導 : 林 一郎教授)

井上 勝 一 郎

九州歯科大学, 北九州, 日本

粉液重合した重合体を顕微鏡で観察すると，重合前に加えられたパール状ポリマ一粒子（粉末 ）の形状が残り，複雑な石坦構造を呈していることがわかる．とのような重合体の応力緩和挙動 は，顕微鏡では何らの構造す観察されない試料，例えば粉末のみを加熱加圧し互いに融着した試 料や有機ガラスなどが示す応力緩和挙動とかなり異なっているものと考えられる，そこで著者は 粉液重合した重合体の応力緩和機構を明らかにするために，つぎの 6 種類の試料について応力緩 和測定ならびに比容積の測定をおこないその挙動を比較検討した.

（1）粉末のみを加熱加圧し融着したもの

(2) 粉液比を $2: 1$ とし歯科的方法で重合したもの

(3)（2）試料を架橋剤ジビニルベンゼンで架橋したもの

(4)（2）の試料を架橋剂ジメタクリル酸グリコールで架橋したもの

(5) 現在市販されている床用レジン

(6) 有機ガラス

その結果次の結論を得た。

1. 粉液重合法で重合した重合体のガラス転移温度は粉末だけを加熱加圧し互いに融着させた 試料や有機ガラスのそれより屯高くなる。また緩和過程における見かけの活性化エネルギ 一屯粉液重合法で作製した試料の方が高い。

2. 同一温度での比容積あるいは温度上昇にと屯なう比容積の増加率 $\left(\frac{\mathrm{d} \nu_{\mathrm{T}}}{\mathrm{d}_{\mathrm{T}}}\right)$ は粉液重合し た試料の方が粉木だけの試料あるいは有機ガラスの場合よりあ大きい.

これらのことから，歯科的方法で重合した重合体では分子は互いにエンタングルメントを起と し物理的なからみ合架橋を起としているものと考えられる。

\section{INTRODUCTION}

Ever since 1947 when polymethyl methacrylate (P.M.M.A.) was first utilized as a denture base material, its demands for several dental usages have rapidly increased, such 


\section{- 444 - FUNDAMENTAL STUDIES ON VISCOELASTICITY OF POLYMETHYL METHACRYLATE POLYMERIZED BY MONOMER-POLYMER TECHNIQUE}

as for denture base material, artificial tooth, tooth restorative material, dental cement, etc.

The viscoelastic behaviour of polymethyl methacrylate has attracted a widespread attention as an interesting subject to study in the industrial circle, and it has been studied in detail by A. V. Tobolsky 1,2), A. E. Woodward ${ }^{3)}$, F. Bueche ${ }^{4)}$, J. D. Ferry ${ }^{5)}$ and others ${ }^{6-8)}$, who are the authorities on polymer physics. And so, almost all the viscoelastic property of $\mathrm{P}$. M. M.A. has been made clear. In their investigations, the method, condition and degree of polymerization are quite different from those used in the dental usages.

In the dental procedures monomer-polymer technique is adopted in order to mould any given shape easily as well as reduce the volume shrinkage and the deformation as small as possible. Therefore, the microscopic structure of the dental acrylic resin polymerized by dental procedure is quite different from that of the industrial acrylic resin obtained by other polymerization techniques. In the former case, the polymer particle which is polymerized by suspension polymerization technique is piled up one another, showing "a stone wall" like structure spread in three dimensions. In the latter case, however, there can be seen no particular structure, except an uniformly translucent appearance.

This difference in the structure may cause whatever effects on the viscoelastic behaviour of polymer.

Though there are a good many dental papers ${ }^{9 \sim 19)}$ on viscoelasticity of polymethyl methacrylate, almost all of them have been written only in the phenomenological standpoint. In molecular level, the stress relaxation mechanism of dental acrylic resin has been discussed in very few of them.

So, the author carried out the measurements of the stress relaxation of dental acrylic resin polymerized by monomer-polymer technique and tried to make clear the stress relaxation mechanism in molecular level.

\section{APPARATUS}

A Apparatus for Stress Relaxation Measurement ${ }^{20,21)}$

The apparatus employed for stress relaxation measurement was the one built up in our laboratory. An over-all picture and a schematic diagram of the apparatus are shown in Fig. 1 and Fig.2, respectively. The apparatus is composed of several important parts, such as a handle(A) to add simple tensile strain to the specimen, a dial gauge(B) to read the amount of strain, two chucks $(\mathrm{C})$ to fix the specimen, an unbonded type strain gauge transducer $(D)$ to evaluate the inner stress stored in the specimen, an oil bath(E) thermally regulated to maintain constant temperature, an $\operatorname{amplifier}(\mathrm{F})$ for the strain gauge transducer, a recorder $(\mathrm{G})$ to record the stress value, an automatic voltage stabilizer $(\mathrm{H})$, and a temperature regulator $(\mathbf{I})$.

The both ends of the specimen are fixed in the chucks, and the specimen is instantaneously pulled to a given length by turning the handle. The amount of elongation added can be read by the dial gauge with accuracy of $1 / 100 \mathrm{~mm}$.

As Fig. 2 shows, the oil bath is a threefold cylindrical glass vessel which contains two 
FUNDAMENTAL STUDIES ON VISCOELASTICITY OF POLYMETHYL METHACRYLATE - 445 POLYMERIZED BY MONOMER-POLYMER TECHNIQUE

glass cylinders, each of them being coiled with a resistance wire. These two glass cylinders, which work as heaters are set in the outer and inner annular spaces of the glass vessel, respectively.

In other words, the vessel consists of three parts, the outer and the middle part are annular baths which are closed in the bottom and each of them contains a cylindrical heater, the central part is a cylindrical, unclosed tube in which the specimen is to be fixed by the chucks. In the two annular baths, heat durable and transparent liquid, silicone oil(TSF433) was filled so that the specimen fixed in the central cylindrical tube (the specimen cell) can be observed from the outside of the oil bath. The temperature of the specimen cell was regulated to be the measuring temperatures within the difference range of $\pm 0.1^{\circ} \mathrm{C}$ by the heater and regulator system.

\section{B Correction of Experimental Data}

The dial-gauge(B) shows the algebraical sum of the specimen elongation and the strain gauge elongation. Therefore, if the absolute value of the strain gauge elongation is quite small as compared to the specimen elongation, this total value of the elongations may be regarded as the specimen elongation itself. But it was not the case, the strain gauge elongation was not so small as to be neglected. Thus, in order to get the real elongation of the specimen, it was necessary to subtract the strain gauge elongation from the total elongation. And so, all the experimental data obtained by the measurement were corrected by subtracting the gauge elongation. The discussion in detail of this correction has already been published by the present author at the 29th general meeting of Kyushu Dental Society.

\section{THEORETICAL BASIS ON MEASUREMENT OF STRESS RELAXATION}

\section{A Stress Relaxation Modulus $\mathrm{E}_{\mathbf{r}}(\mathrm{t})$}

According to Hooke's law, stress relaxation modulus is defined by the following equation.

$$
E_{r}(t)=\frac{f(t)}{r}
$$

where $f(t)$ is the relaxation stress, $r$ is the strain.

B Application of Time-Temperature Supperposition Principle

For the amorphous polymer like polymethyl methacrylate, it is well known that a curve of relaxation moduli versus time at a temperature can be superimposed to a certain other curve at different temperature by shifting along the logarithmic time axis. This fact can be used to make up a very wide time range curve of relaxation moduli. In order to practice this procedure (reduced variable method), the measured stress relaxation modulus is necessary to be corrected to the reduced value by the following equation ${ }^{22}$.

$$
E_{r}(t)_{\text {red }}=\frac{T_{o} d_{\circ}}{T d} E_{r}(t)
$$

where $E_{r}(t)_{r e d}$ is the reduced stress relaxation modulus, $E_{r}(t)$ is the measured stress relaxation modulus, $d_{o}$ is the density of specimen at standard temperature $\left(T_{\circ}^{\circ} \mathrm{K}\right)$, $\mathrm{d}$ is the density of specimen at each measuring temperature $\left(\mathrm{T}^{\circ} \mathrm{K}\right)$.

Equation(2) can be led by the theory of rubbery elasticity. In the present experimental 
conditions, the change of specimen density was so small that the difference of density could be neglected practically. Therefore, equation(2) may be expressed as follows:

$$
E_{r}(t)_{r e d}=\frac{T_{o}}{T} E_{r}(t)
$$

By using equation(3), the stress relaxation moduli obtained at the different temperatures were transfered to the reduced stress relaxation moduli.

Then, the curves of reduced stress relaxation moduli versus time at various temperatures were superimposed on a curve at a chosen, standard temperature by shifting them. By equating the amount shifted along the logarithmic time axis to $\log a_{\mathrm{T}}$ the following equation is obtained.

$$
\log \mathrm{t}-\log \mathrm{t}_{\mathrm{o}}=\log a_{\mathrm{T}}
$$

where $a_{\mathrm{T}}$ is shift factor, $\mathrm{t}$ and $\mathrm{t}_{\mathrm{o}}$ are the times in the shifted and the standard curve, respectively, at which the stresses are identical.

According to the theory of viscoelasticity, the relation between $\log a_{\mathrm{T}}$ and $(\mathrm{T}-\mathrm{Tg})^{\circ} \mathrm{K}$ is shown by the following equation(WLF equation) ${ }^{23 \sim 26)}$, when the glass transition temperature $(\mathrm{Tg})$ is chosen as the standard temperature,

$$
\log a_{\mathrm{T}}=-\frac{17.44(\mathrm{~T}-\mathrm{Tg})}{51.6+\mathrm{T}-\mathrm{Tg}}
$$

C Apparent Activation Energy in Stress Relaxation Procedure ${ }^{27 \sim 29)}$

When WLF equation is satisfied, the apparent activation energy for stress relaxation procedure is given by the following equation,

$$
\triangle \mathrm{H}=2.303 \mathrm{R} \frac{\mathrm{d}\left(\log a_{\mathrm{T}}\right)}{\mathrm{d}\left(\frac{1}{\mathrm{~T}}\right)}
$$

where $\mathrm{R}$ is gas constant, $\mathrm{T}$ is the measuring temperature $\left({ }^{\circ} \mathrm{K}\right), a_{\mathrm{T}}$ is shift factor.

Substituting equation(5) into equation(6), the following equation is obtained,

$$
\triangle \mathbf{H}=\frac{4.12 \times 10^{3} \mathrm{~T}^{2}}{(51.6+\mathrm{T}-\mathrm{Tg})^{2}}
$$

D Distribution of Relaxation Times (First Approximation) ${ }^{30 \sim 31)}$

The distribution of relaxation time, $\operatorname{Er}(\tau)$, is defined by the following equation,

$$
E_{r}(t)=\int_{0}^{\infty} E_{r}(\tau) \exp \left(-\frac{t}{\tau}\right) d \tau
$$

The function $H(\ln \tau)$ which expresses the distribution function of relaxation times in terms of $\ln \tau$ is related to $E_{r}(\tau)$ by the following equation,

$$
\mathrm{E}_{\mathrm{r}}(\tau)=\frac{\mathrm{H}(\ln \tau)}{\tau}
$$

Being differentiated, equation(9) is shown as follows:

$$
H(\ln \tau) d(\ln \tau)=E_{r}(\tau) d \tau .
$$

Therefore, equation(8) is transfered to the following form:

$$
E_{r}(t)=\int_{0}^{\infty} H(\ln \tau) \exp \left(-\frac{t}{\tau}\right) d(\ln \tau) .
$$


FUNDAMENTAL STUDIES ON VISCOELASTICITY OF POLYMETHYL METHACRYLATE - 447 POLYMERIZED BY MONOMER-POLYMER TECHNIQUE

In the first approximation,

$$
\exp \left(-\frac{\mathrm{t}}{\tau}\right)=\left\{\begin{array}{l}
1(\text { when } 0<\tau<\mathrm{t}) \\
\mathrm{o}(\text { when } \mathrm{t}<\tau)
\end{array}\right.
$$

and equation(10) can be simplified as follows:

$$
\begin{aligned}
H(\ln \tau) & =-\left[\frac{d \ln E(t)}{d(\ln t)}\right]_{t=\tau,} \\
\text { or, } \quad H(\ln \tau) & =-\left[\operatorname{Er}(t) \frac{d \ln E(t)}{d(\ln t)}\right]_{t=\tau .}
\end{aligned}
$$

\section{MATERIALS}

\section{A Materials}

The materials employed for the experiment are polymethyl methacrylate (lst class commer cial reagent polymerized by pearl polymerization method and having nearly the same average particle size and viscosity-average molecular weight with ordinary denture base resin powders), organic glass (Acrylite) and a commercial denture base resin. The average size of particles, determined by 'average particle size detector', and the viscosity-average molecular weight, determined by Cannon Fenske viscometer ${ }^{32}$ ) using benzene as the solvent of polymer in pearly state, were 68.69 microns and 430000 , respectively. As hydroquinone is added in all the commercial monomers to inhibit polymerization by oxygen or ultra-violet rays, three times vacuum distilled monomer was employed. Benzoyl peroxied (0.5 weight percent of monomer) was used as accelerator for polymerization of monomer. Two kinds of crosslinked polymer were made by the author in order to illustrate more clearly the viscoelastic behaviour of polymer obtained by monomer-polymer technique. Two kinds of reagent for crosslinking were used: divinyl benzene to the one and ethyl dimethacrylate to the other. The added amount of each reagent for crosslinking was 1 weight percent of the monomer. Table 1 shows the techniques and monomer-polymer ratios employed for making the specimens.

\section{B Speimens}

Specimen A was made by the following technique: first the polymer in the pearly state is put between two smoothly polished brass boards and is inserted in soft contact between two pressing blocks of an oil-press heated to $180^{\circ} \mathrm{C}$ by heaters in it, and then is sintered together into a film state by pressing at a suitable pressure for ten minutes. The temperature and the pressure were chosen just because of the easiness in making the film.

Specimens B, C, D and E were made by essentially the same as the dental curing technique utilizing the oil-pressure. As in the case of specimen $A$, the mixtures of monomer and polymer of these specimens are put between the two brass boards and are pressed by oilpress to a suitable pressure. The mixture, pressed into a film state, is heated gradually to reach $100^{\circ} \mathrm{C}$ in thirty minutes, and after keeping the temperature at $100^{\circ} \mathrm{C}$ for an hour it cooled rapidly to the room temperature by water.

The specimen $\mathrm{F}$ was made by just the same way as in the case of specimen $\mathrm{A}$. Organic glass, put between the two brass boards, is $50 \times 10 \times 3 \mathrm{~mm}^{3}$ in size. It is pressed by the oil- 
- 448 - FUNDAMENTAL STUDIES ON VISCOELASTICITY OF POLYMETHYL METHACRYLATE POLYMERIZED BY MONOMER-POLYMER TECHNIQUE

press at $180^{\circ} \mathrm{C}$, gradually increasing the pressure in about 10 minutes, so that it becomes $0.25 \sim 0.3 m m$ thick. The final thickness of films is $0.25 \sim 0.3 m m$ in all the specimens. The test specimens were cut off by using a safety razor blade from these films, and the size of it is $1.10 \sim 1.20 \mathrm{~mm}$ in width and $50 \mathrm{~mm}$ in length. As it is considered that all the test specimens have been strained in the polymerizing and cooling processes, a heat treatment was practiced for them. Namely, they were cooled gradually to room temperature after keeping them for six hours in nitrogen gas $\left(100^{\circ} \mathrm{C}\right)$.

\section{METHOD}

\section{A Stress Relaxation Measurment}

As shown in Fig. 2, the test specimen is set by chucks $C$ and a certain strain is added to the specimen by turning handle A.

According to the theory of linear viscoelasticity the strain, added to the specimen must be confined within a limit so as to the linearity can be maintained between stress and strain. From the results of a preliminary experiment, it was found that the linearity could be maintained when the added strain was below $0.26 \%$. Therefore, in all the experiments, the adding strain was confined to be less than $0.26 \%$.

B Measurement of Specific Volume at Various Temperatures

A pycnometer was used for measurement of specific volume at $33^{\circ} \mathrm{C}$, and a mercury dilatometer ${ }^{33)}$ for the measurement of the changes of specific volume by rising the temperature. The specimen cell of dilatometer was heated starting from $33^{\circ} \mathrm{C}$ at the rate of $0.5^{\circ} \mathrm{C} / \mathrm{min}$ by an oil bath. The expansion of specimen and mercury can be visualized by the rising of mercury in the capillary. The height of mercury rise is measured by comparator to the accuracy of $1 / 100 \mathrm{~mm}$.

The real expansion of specimen is obtained by subtracting the expansion of mercury from the total expansion.

The specific volume $\left(\nu_{\mathrm{T}}\right)$ at a temperature $\left(T^{\circ} \mathrm{C}\right)$ can be expressed by the following equation:

$$
\nu_{\mathrm{T}}=\frac{\mathrm{v}_{33}+\mathrm{A}\left(\mathrm{h}_{\mathrm{T}}-\mathrm{h}_{33}\right)-\alpha_{\mathrm{Hg}}(\mathrm{T}-33)}{\mathrm{m}}
$$

where $V_{33}$ is the volume of specimen at $33^{\circ} \mathrm{C}, \mathrm{A}$ is the cross section area of capillary, $\mathrm{h}_{\mathrm{T}}$, $\mathrm{h}_{33}$ are the height of mercury in the capillary at $\mathrm{T}^{\circ} \mathrm{C}$ and $33^{\circ} \mathrm{C}$, respectively, $\alpha_{\mathrm{Hg}}$ is the coefficient of thermal expansion, and $\mathrm{m}$ is the mass of specimen.

The measurement of specific volume carried out only for specimens A, B, C and D. The temperature range of measurement was from 37 to $130^{\circ} \mathrm{C}$.

\section{RESULTS}

A Stress Relaxation Modulus $\mathrm{E}_{\mathrm{r}}(\mathrm{t})$ and Glass Transition Temperature ( $\mathrm{Tg}$ )

Figs. 3-8 illustrate the temperature dependence of $E_{r}(t)$ of the six kinds of specimen. The values of $E_{r}(t)$ of each specimen are shown in Tables 2-7, 
FUNDAMENTAL STUDIES ON VISCOELASTICITY OF POLYMETHYL METHACRYLATE - 449 POLYMERIZED BY MONOMER-POLYMER TECHNIQUE

At the transition temperature $(\mathrm{Tg})$ the relaxation modulus decreases remarkably, as well as the state of specimen changes drastically from glassy to rubbery. Specimen A showed the lowest transition temperature $\left(85^{\circ} \mathrm{C}\right)$ among the six kinds of specimen.

The rubbery plateau region, at which the relaxation modulus is about $10^{7} \mathrm{dyne} / \mathrm{cm}^{3}$ could hardly be observed.

In comparison with specimen $\mathrm{A}$, specimen $\mathrm{B}$ showed $10^{\circ} \mathrm{C}$ higher glass transition temperature and a narrow rubbery plateau region could be observed. Specimen $C$ and $D$, the crosslinked polymers, had higher glass transition temperatures than specimen $\mathrm{B}$ and showed a clear rubbery plateau. Specimen $\mathrm{E}$ is a commercial denture base resin of heat curing type, whose stress relaxation behaviour in the transition region is similar to that of specimens $\mathrm{B}, \mathrm{C}$ and $\mathrm{D}$.

That is, the decreasing rate of relaxation moduli versus temperature of specimen $\mathrm{E}$ is greater than those of specimen A and F. Its glass transition temperature was the greatest of all the six kinds of specimen tested in the experiment. The stress relaxation behaviour of specimen $F$ was similar to that of specimen $A$ and the curve of $E_{r}(t)$ versus $\log t$ was nearly a straight line within the transition region. The glass transition temperature of specimen $\mathrm{F}$ was nearly $90^{\circ} \mathrm{C}$, a little higher than that of specimen $\mathrm{A}$.

Fig. 9 illustrates the temperature dependence of the stress relaxation moduli $E_{r}(t)$ at 5 seconds after the measurement was begun. According to this curve, the transition temperatures of specimen B, C, D, and E, which were polymerized by the dental method, are all higher than specimen $\mathrm{A}$ or $\mathrm{F}$. The values of glass transition temperature are shown in Table 8.

The glass transition temperature can be determined exactly by measuring the specific volume. The free volume of a specimen becomes to increase more rapidly when its temperature exceeds the glass transition temperature than when its temperature does not reach to that temperature. So, the slope of specific volume versus temperature curve changes drastically at the glass transition temperature.

Utilizing this property the author determined the glass transition temperatures of the specimens.

The values of specific volume and glass transition temperature are shown in Table 8 and 9, respectively. Fig. 10 shows the curves of specific volume versus temperature.

B Application of Time-Temperature Superposition Principle

Fig. 11 is a master relaxation curve obtaind by shifting $\log E_{r}(t)-\log t$ curves at all other temperatures along the logarithmic time axis to superpose on a standard curve at an arbitrarily chosen temperature. The standard temperature was chosen as follows: $37^{\circ} \mathrm{C}$ for specimen $\mathrm{A}, \mathrm{B}, \mathrm{C}$ and $\mathrm{D}, 32.5^{\circ} \mathrm{C}$ for specimen $\mathrm{E}, 32^{\circ} \mathrm{C}$ for specimen F. Fig. 12 illustrates the relation between shift factor $\left(\log a_{\mathrm{T}}\right)$ and temperature of each shifted curve. Since the absolute value of slope of the curve $\left(-\frac{\mathrm{d} \log a_{\mathrm{T}}}{\mathrm{dT}}\right)$ is stress relaxation rate, the temperature at which the absolute value of $\left(\frac{\mathrm{d} \log a_{\mathrm{T}}}{\mathrm{dT}}\right)$ becomes the greatest should accord to the glass 


\section{- 450 - FUNDAMENTAL STUDIES ON VISCOELASTICITY OF POLYMETHYL METHACRYLATE POLYMERIZED BY MONOMER-POLYMER TECHNIQUE}

transition temperature of specimen.

Two groups of glass transition temperature are shown in Table 9, the one obtained by the measurement of specific volume and the other by the measurement of stress relaxation. Figs. 13-16 show the specific volume change by temperature rise and the temperature dependence of $\left(\frac{\mathrm{d} \log a_{\mathrm{T}}}{\mathrm{dT}}\right)$ in specimens $\mathrm{A}, \mathrm{B}, \mathrm{C}$ and $\mathrm{D}$. From these curves it is apparent that $\mathrm{B}, \mathrm{C}$ and $\mathrm{D}$ (excepting $\mathrm{A}$ ) have almost the same glass transition temperature. The relation between $\left(\frac{\mathrm{d} \log a_{\mathrm{T}}}{\mathrm{dT}}\right)$ and temperature is shown in Table 10-13.

C Apparent Energy of Activation in Process of Stress Relaxation

When the glass transition temperature of specimen was chosen as a standard temperature of master relaxation curve, it was found that the amount of shift $\left(\log a_{\mathrm{T}}\right)$ of each curve satisfied WLF equation shown by equation(5). Therefore, the apparent activation energy in stress relaxation process could be calculated by using equation(7). The results are shown in Tables 18-21. Fig. 18 shows the curves of data in Table 16-19.

D Distribution of Relaxation Times

Fig. 19 shows the distribution of stress relaxation time at $37^{\circ} \mathrm{C}$ calculated by using equation(12). The peaks of the distribution curve of stress relaxation times were observed at $10^{10}$ seconds in specimen $A, 10^{11}$ seconds in specimen $B, 10^{16} \sim 10^{17}$ seconds in specimens $\mathrm{C}, \mathrm{D}, \mathrm{E}$ and $10^{12}$ seconds in specimen $\mathrm{F}$. The distribution of stress relaxation time is shown in Table 22.

\section{DISCUSSION}

In comparison with specimen $B$ which was polymerized by dental technique, specimen A which was prepared by sintering polymer particles together has a smaller decreasing rate $\frac{-\mathrm{d} E_{\mathrm{r}}(\mathbf{t})}{\mathrm{dt}}$ of modulus within the glass transition region, and it has also a lower glass transition temperature (Figs. $3,4,8$; Table 6 ). In the case of specimen $A$, the glass transition temperature obtained by stress relaxation rate is lower than the temperature obtained by specific volume measurement.

In the case of specimen $\mathrm{B}$, the two temperatures are nearly the same (Figs. 13, 14, ). It seems that the difference seen above may depend on the different degree of entanglement of molecular chain between specimen $A$ and $B$. In specimen $A$ obtained by sintering polymer particles together, it is considered that the diffusion of molecule is not so easy. And so the molecular entanglements are rather few. When molecular motion becomes vigorous by the temperature rise, the entanglement of molecular chain will easily be loosened and the stress, stored in specimen, relaxed. It may be for this reason that a remarkable decrease of relaxation modulus occurred at a much lower temperature than glass transition temperature in the case of specimen $\mathrm{A}$.

On the contrary, in the monomer-polymer technique, namely, the dental method, it is supposed that the inner part of polymer particles is nearly saturated by added monomer and the specimen obtained has more entanglements of molecular chain than the sintered 
FUNDAMENTAL STUDIES ON VISCOELASTICITY OF POLYMETHYL METHACRYLATE - 45I POLYMERIZED BY MONOMER-POLYMER TECHNIQUE

specimen A. Both the glass transition temperature and the absolute value of decreasing rate of relaxation modulus in transition region of specimen $B$ are higher than those of specimen A. These facts may be considered to be macro manifestations of micro property difference that the entanglements in specimen $B$ are harder to be loosened than those in specimen $A$.

The fact that the energy versus temperature curves of specimen $B$ are to be shifted towards higher temperatures than the curves of specimen A means that a higher energy is necessary for specimen $B$ to be caused relaxation flow than for specimen $A$.

As for the distribution curve of stress relaxation time, the peak is located at a longer time in specimen B than in specimen A. This also means that it is harder for specimen B's relaxation flow to be caused than specimen A (Figs. 18, 19 ; Tables 16, 17, 22). Specimens $\mathrm{C}$ and $\mathrm{D}$ are crosslinked polymer, and each of them shows a higher glass transition temperature than specimens $\mathrm{A}$ and B. And they show clear rubbery plateau region (Figs. 5, 6). The $\frac{\mathrm{d} \log a_{\mathrm{T}}}{\mathrm{dT}}-\mathrm{T}$ curves of them have a sharp mountain-like form as specimen $\mathrm{B}$ and the glass transition temperatures obtained by these curves accord with those obtained by the specific volume versus temperature curves of them (Figs. 15, 16 ; Table 10).

From the fact that the apparent activation energies in stress relaxation process of specimen $\mathrm{C}$ and $\mathrm{D}$ are higher than specimen $\mathrm{B}$; specimen $\mathrm{C}$ and $\mathrm{D}$ may be said to be much harder to be relaxed than specimen B (Fig. 18).

Specimen $\mathrm{E}$ is a commercial denture base resin, whose glass transition temperature is about the same as that of specimen B and its rubbery plateau region is the widest (Fig. 7). Its apparent activation energy in stress relaxation process is the greatest of all (215 kcal/ mol) at the glass transition temperature (Fig. 18 ; Table 20).

In the distribution curve of stress relaxation times of specimen $\mathrm{E}$, the peak is seen at $10^{16}$ seconds and shifted to a much longer time than that of specimen B. From the fact that this distribution curve almost conforms to those of specimens $C$ and $D$, it may be supposed that a considerable amount of crosslinking reagent is added to specimen $\mathrm{E}$.

Specimen $F$ is organic glass film obtained by heating and pressing a commercial organic glass board under the same conditions as in specimen A. Its stress relaxation behaviour is similar to that of specimen $\mathrm{A}$, and within the glass transition region it has a smaller absolute value of slope in the $\log E_{r}(t)-\log t$ curve than specimen $A$ (Figs. 8, 11). Its glass transition temperature and the apparent activation energy in stress relaxation process is between those of specimen A and B (Figs. 17, 18; Table 21). Its peak in distribution curve of stress relaxation times is seen at $10^{12}$ seconds. From these experimental results, it can be said that specimen $\mathrm{F}$ has not so many entanglements of molecular chain as specimen B.

\section{CONCLUSION}

Fron the considerations above mentions the author concluded as follows:

1 The specimen polymerized by the dental technique presents a higher transition temperature than specimen $\mathrm{A}$ and $\mathrm{F}$, obtained by other methods, and its viscoelastic behaviour is similar to that of the crosslinked polymer. From these facts, it is considered that 


\section{— 452 - FUNDAMENTAL STUDIES ON VISCOELASTICITY OF POLYMETHYL METHACRYLATE POLYMERIZED BY MONOMER-POLYMER TECHNIQUE}

polymers obtained by monomer-polymer curing technique have more temporary physical crosslinks provided by molecular chain entanglements than polymers obtained by other methods.

2 It is difficult to create physical crosslinks (provided by chain entanglement) by sintering a short time.

3 The increasing rate of specific volume of specimen $B$ polymerized by the dental technique is greater than of specimen A moulded by sintering. The higher the temperature over the point of the glass transition temperature the greater becomes the difference between the rates in $\mathrm{A}$ and $\mathrm{B}$.

4 The glass transition temperature of the crosslinked polymer is higher than that of the uncrosslinked polymer. Therefore, the former requires longer time for applied stress to be relaxed than the latter.

5 The apparent activation energy in stress relaxation process of Funcrosslinked specimen polymerized by the dental technique is $210 \mathrm{kcal} / \mathrm{mol}$ at glass transition temperature, which is higher than that of organic glass board at the glass transition temperature.

6 In the distribution curve of stress relaxation time at $37^{\circ} \mathrm{C}$ of uncrosslinked specimen polymerized by the dental technique, the peak comes around $10^{11}$ seconds.

7 It became clear that the commercial denture base resin tested in the experiment contained some crosslinking reagent.

These are the conclusions of the experiment. The author may safely say that the stress relaxation mechanism of polymer polymerized by monomer-polymer technique could be made considerably clear. Polymer polymerized by dental technique has remarkable entanglements of molecular chain showing viscoelastic behaviour similar to that of chemically crosslinked polymer. And compared with the specimen moulded by sintering polymer particles together or with organic glass, it is harder for its inner stresses to be relaxed. Consequently dental curing method which is now employed in dentistry can be estimated to be a good curing method as far as the viscoelastic behaviour of the produced polymer is concerned.

\section{ACKNOWLEDGEMENT}

The author is indebted to Professor Ichiro HAYASHI for his kind and helpful advices. And also the author should like to acknowledge the cooperation for this work to the staffs of Dental Physicotechnology Laboratory of Kyushu Dental College.

\section{REFERENCES}

1. J.R. McLoughlin, A. V. Tobolsky; The viscoelastic behaviour of polymethyl methacrylate : J. Polymer Sci., 5, 555-568, (1952).

2. A. V. Tobolsky ; Properties and structure of polymers: John Wiley and Sons, Chaps. 3-4, (1960).

3. A. E. Woodward; The dynamic mechanical properties of high polymers at low temperatures: Fortschr. Hochpolym. Porsch., Bd. 1, 114-158, (1958). 

POLYMERIZED BY MONOMER-POLYMER TECHNIQUE

4. F. Bueche; Physical properties of polymers: John Wiley and Sons, Chaps. 4-11, (1962).

5. J.D.Ferry; Viscoelastic properties of polymers: John Wiley and sons, 201-319, (1960).

6. A.G. Fredrickson ; Principles and applications of rheology : Pretice-Hall, 122-125, (1964).

7. S. Onogi; Kobunshi no rikigakuteki seishitsu (Translated from L. E. Nielsen's physical propetries of polymer): Kagakudojin, 74-88, (1965).

8. K. Goto, N. Hirai, T. Hanai; Reoroji to sono ohyo: Kyoritsu, 73-99, (1964).

9. M. Braden, C.D.Stafford; Viscoelastic properties some denture base materials : J. D. R. , 47 (4), 519-523, (1968).

10. M. Braden, G. D. Stafford ; The absorption of water by acrylic resins and other mate. rials: J. P. D., 14 (2), 307-316, (1964).

11. E.W.Skinner, R.W.Phillipes; The Science of Dental Materials : W. B.Saunders, 153(1960).

12. K. Inoue, I. Hayashi; Glass temperature of dental resin: J. K. D. C., 21(3), 238-240, (1967).

13. K. Inoue, I. Hayashi; $37^{\circ} \mathrm{C}$ suichyu ni okeru shihanshyoyorejin no nendanseitekikyodo: J. D. A. M., (14), 89-92, (1967).

14. I. Hayashi, M. Yamane; Shikayorejin no rikigakuteki seishitsu (No.1): J. D. A. M., 2 (2), 55-57, (1961).

15. K. Inoue, I. Hayashi; Shikayorejin no rikigaknteki seishitsu (No. 2) : J. D. A. M., 4 (6), 59-64, (1963).

16. K. Inoue, I. Hayashi; Shikayorejin no rikigakuteki seishitsu (No.3): J. D. A. M., 5 (9), 121-125, (1965).

17. F. A.Peyton; Restorative dental materials: The C. V. Mosby Company, 461-465, (1968).

18. I. Hayashi; Fundamental studies on the internal stress of dental resin: Shikaigaku, 28 (1), 66-97, (1965).

19. K. Inoue, I. Hayashi ; Dynamic viscoelasticity of dental resin: J. D. A. M., 9 (16), 11-14, (1968).

20. Kobunshingakkai Reoroji Iinkai; Reoroji sokuteiho: Kyoritsu, 144-159, (1965).

21. J.R. V. Wazer, J. W. Lyons, K. Y. Kim, R. E. Colwell ; Viscosity and Flow Measurement: John Wiley and Sons, 344-369, (1963).

22. S. Onogi; Kobunshi no rikigakuteki seishitsu (Translated from L. E. Nielsen's physical properties of polymer): Kagakudojin, 85-88, , (1965).

23. A. V. Tobolsky; Properties, and structure of polymers: John Wiley and Sons, 83-88, (1960).

24. T. Imoto; Gaisetsu reoroji (2): Tokyo Kagakudojin, 124-138, (1963).

25. Y. Wada; Kobunshi no kotai bussei: Baifukan, 53-58, (1971). 
- 454 - FUNDAMENTAL STUDIES ON VISCOELASTICITY OF POLYMETHYL METHACRYLATE POLYMERIZED BY MONOMER-POLYMER TECHNIQUE

26. Nihon Butsuri Gakkai; Kobunshi no butsuri: Asakura, 153-158, (1963).

27. H. Kanbe, K. Murakami; Ohyo reoroji: Nikkan Kogyo, 116-120, (1963).

28. Nihon Butsuri Gakkai; Kobunshi no butsuri: Asakura, 175-177, (1963).

29. J.D.Ferry; Viscoelastic properties of polymers: John Wiley and Sons, 224-227, (1960).

30. J.R. McLoughlin, A. V. Tobolsky ; The viscoelastic behaviour of polymethyl methacrylate: J. Polymer Sci., 5, 564-567, (1952).

31. K. Goto, N. Hirai, T. Hanai; Reoroji to sono ohyo: Kyoritsu, 95-97, (1964).

32. Nihon Kagakukai; Jikkenkagakukoza kohbunshikagaku (1): 123-157, (1956).

33. Nihon Kagakukai; Jikkenkagakukoza kohbunshikagaku (2): 84-96, (1956).

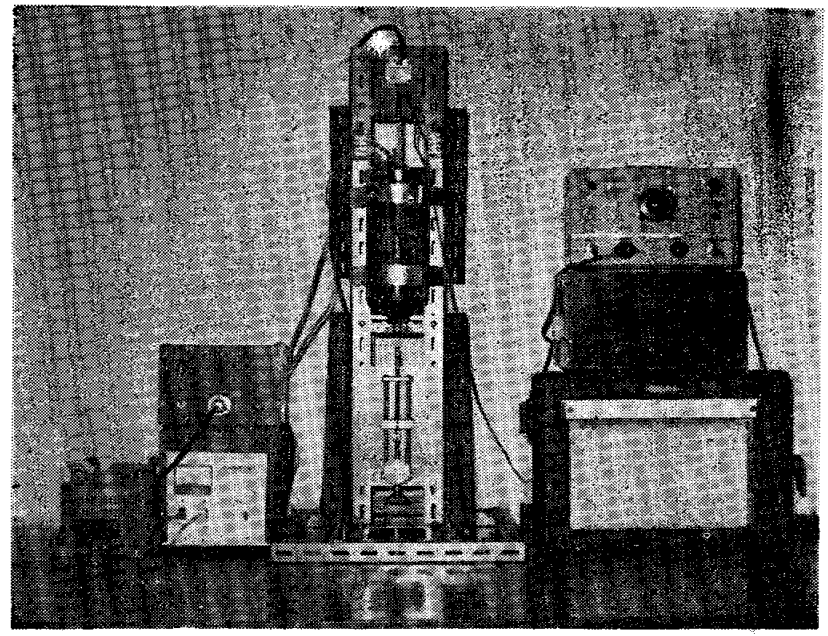

Fig. 1 Stress Relaxation Apparatus

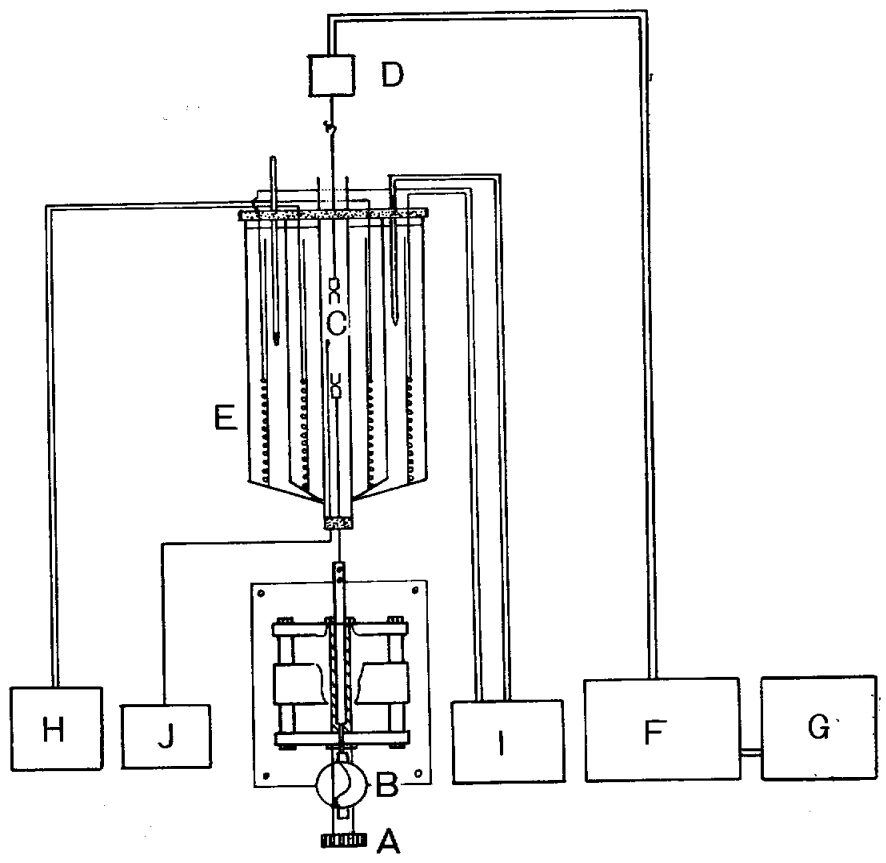

Fig. 2 Schematic Diagram showing the Principle of Stress Relaxation Apparatus

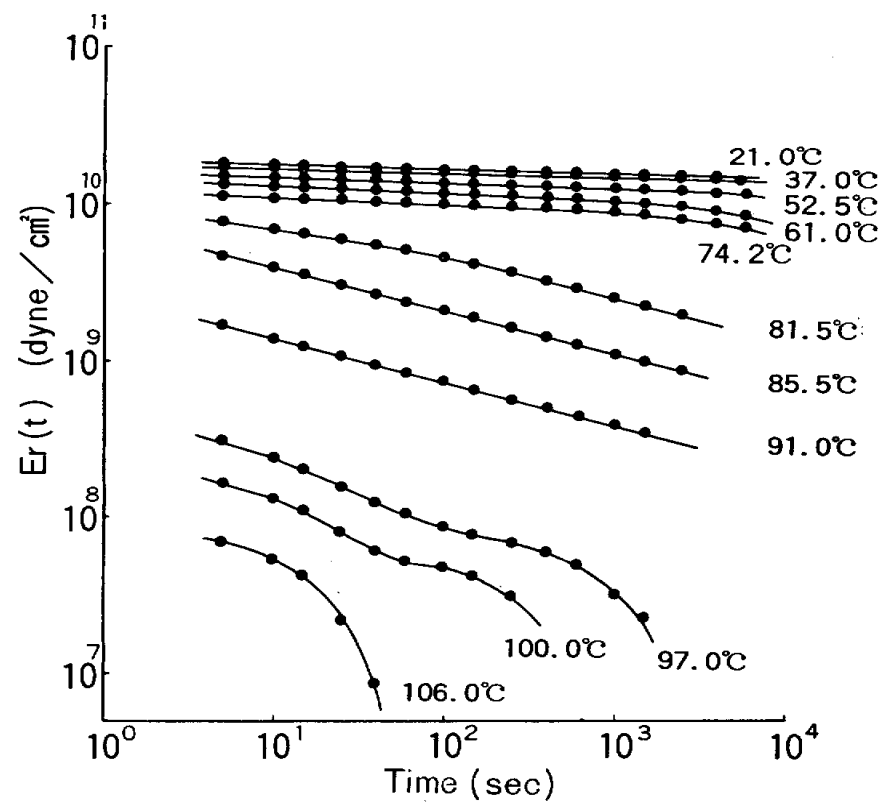

Fig. 3 Measured Stress Relaxation Moduli $\left\{E_{:}(t)\right\}$

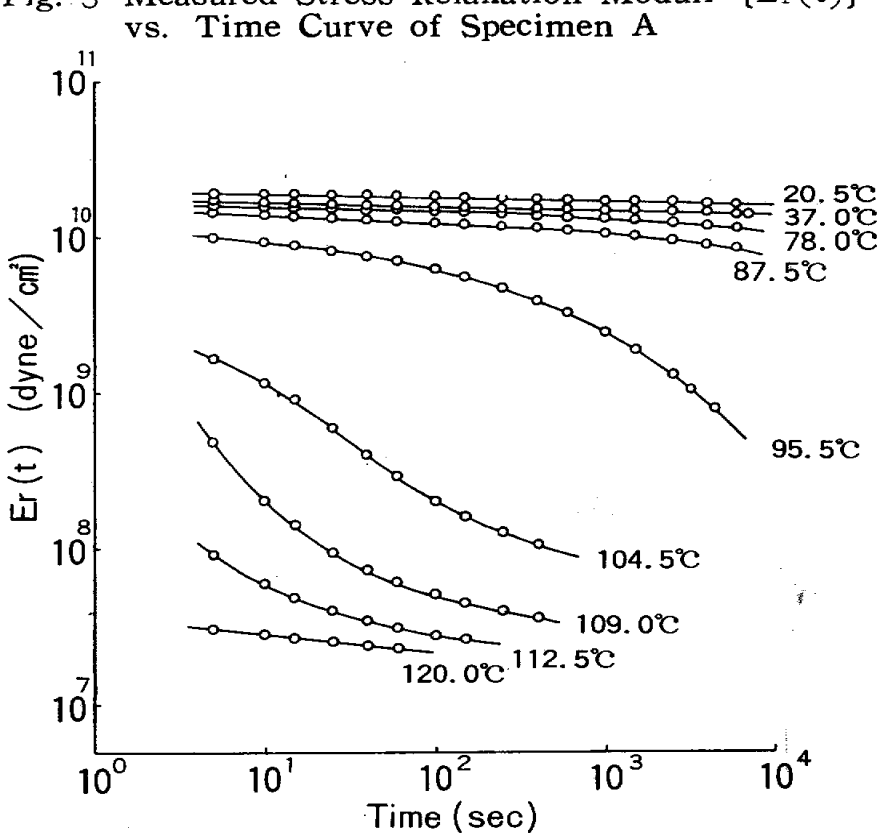

Fig. 4 Measured Stress Relaxation Moduli $\left\{\mathbf{E}_{\mathbf{r}}(\mathbf{t})\right\}$ vs. Time Curve of Specimen B 
FUNDAMENTAL STUDIES ON VISCOELASTICITY OF POLYMETHYL METHACRYLATE - 455 POLYMERIZED BY MONOMER-POLYMER TECHNIQUE

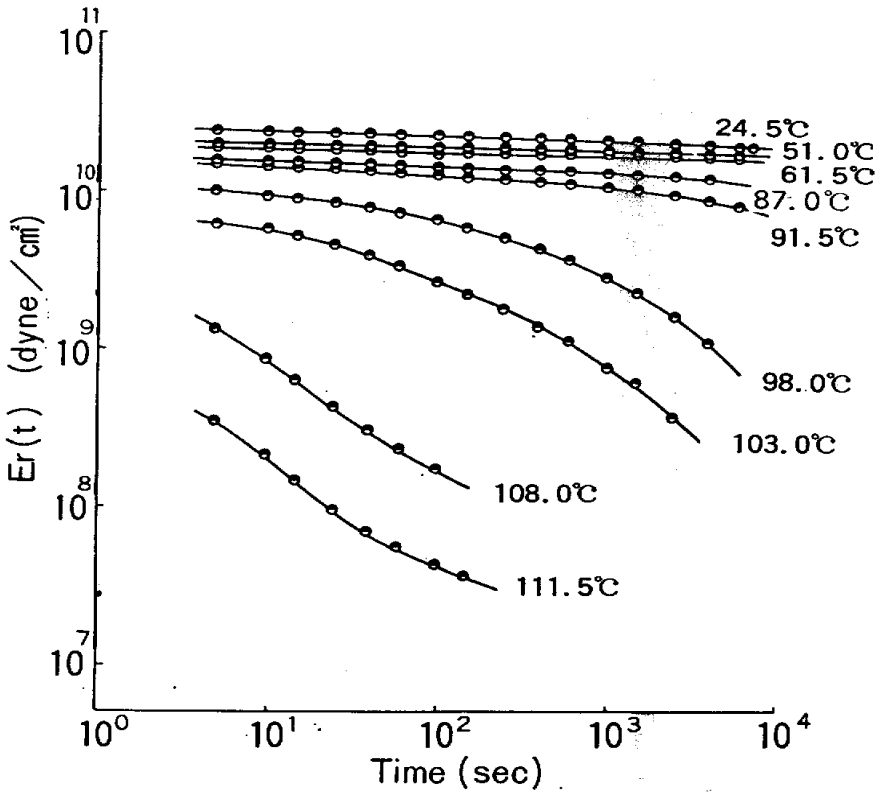

Fig. 5 Measured Stress Relaxation Moduli $\left\{E_{r}(t)\right\}$ vs. Time Curve of Specimen C

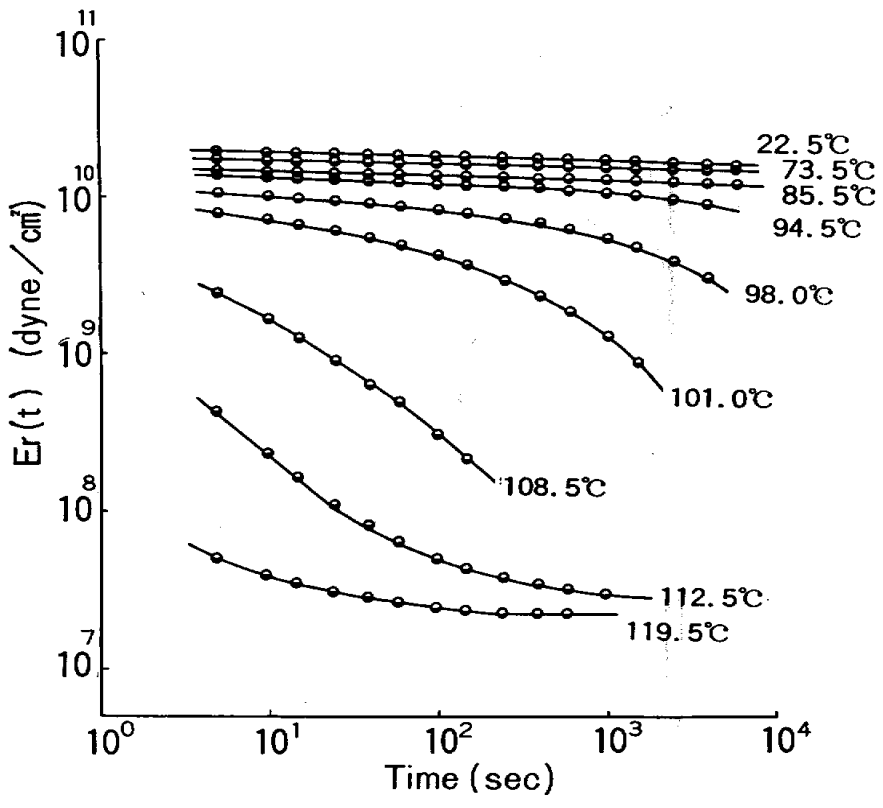

Fig. 6 Measured Stress Relaxation Moduli $\left\{E_{r}(t)\right\}$ vs. Time Curve of Specimen D

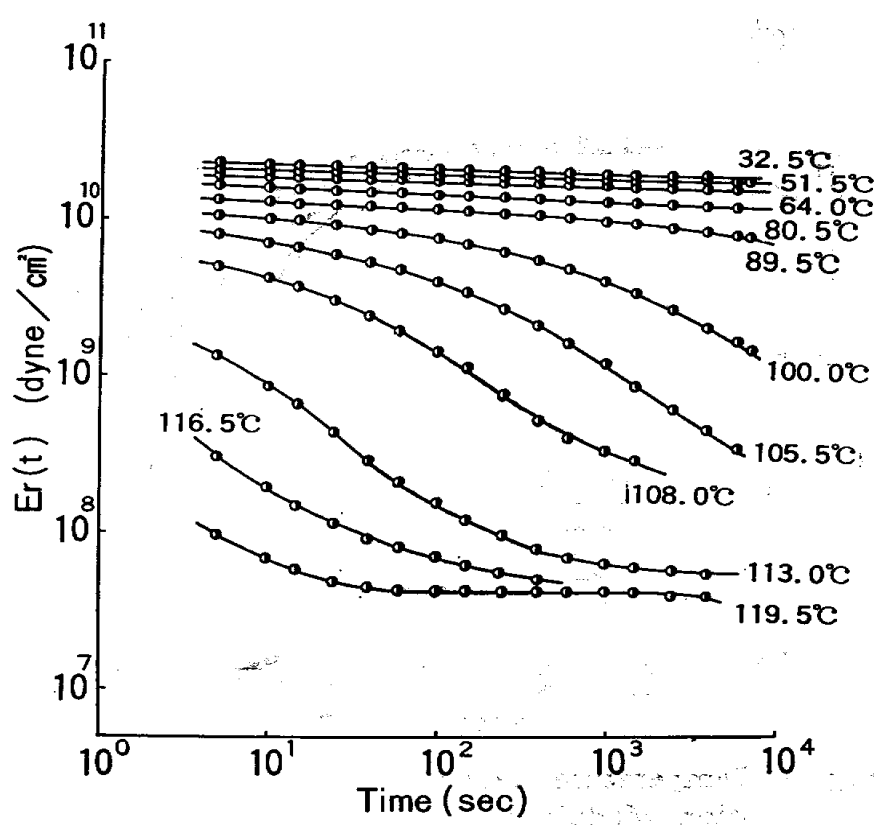

Fig. 7 Measured Stress Relaxation Moduli $\left\{E_{r}(t)\right\}$ vs. Time Curve of Specimen E

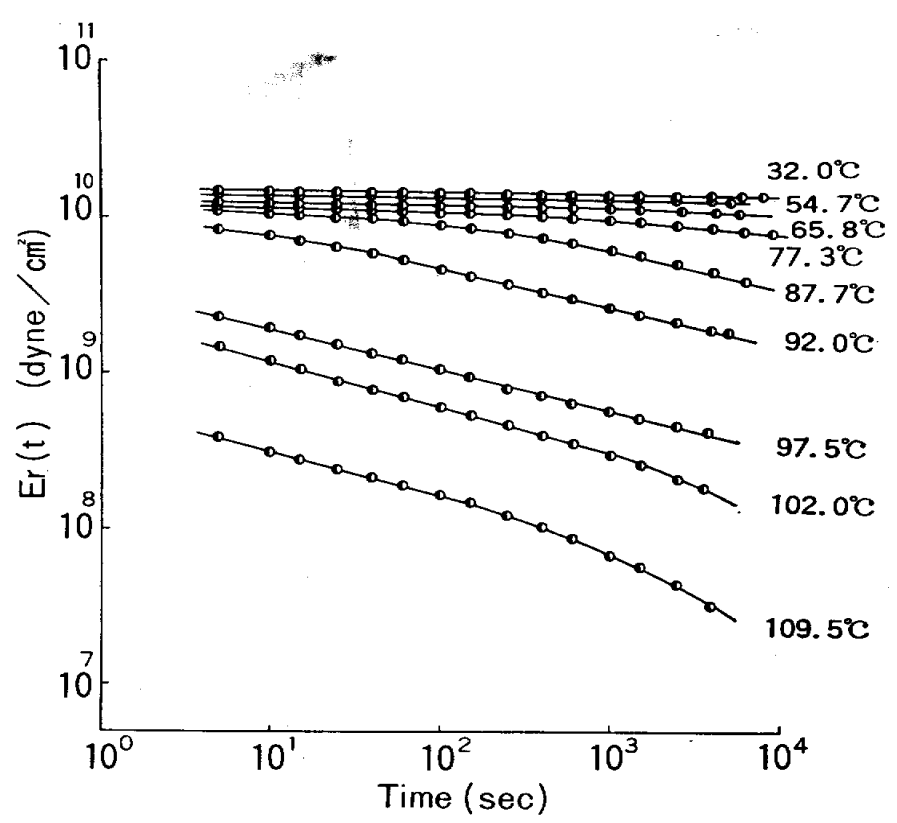

Fig. 8 Measured Stress Relaxation Moduli $\left\{\mathrm{E}_{\mathrm{r}}(\mathrm{t})\right\}$ vs. Time Curve of Specimen F 


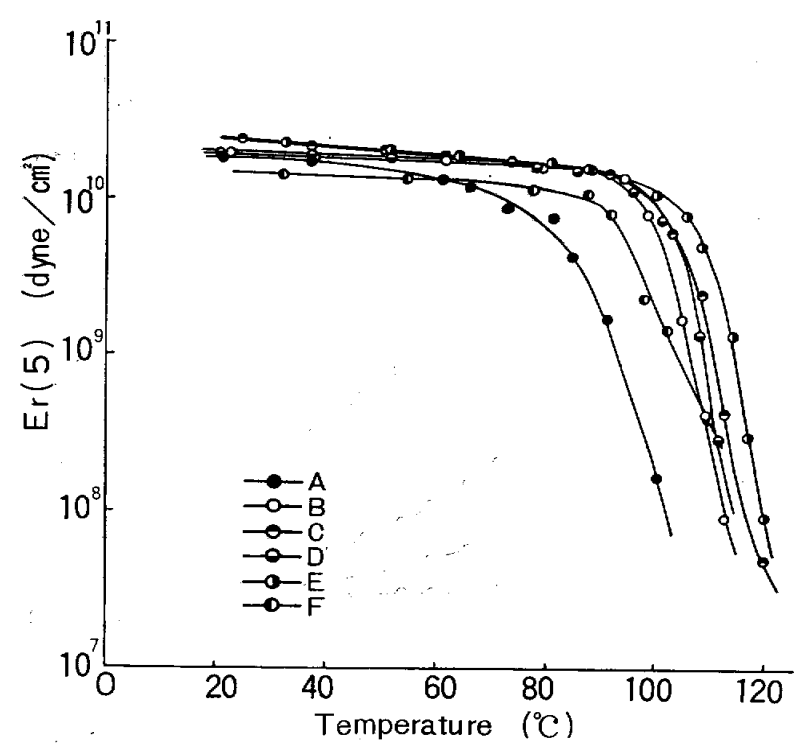

Fig. 9 Temperature Dependence of Stress Relaxation Moduli $\operatorname{Er}(5)$

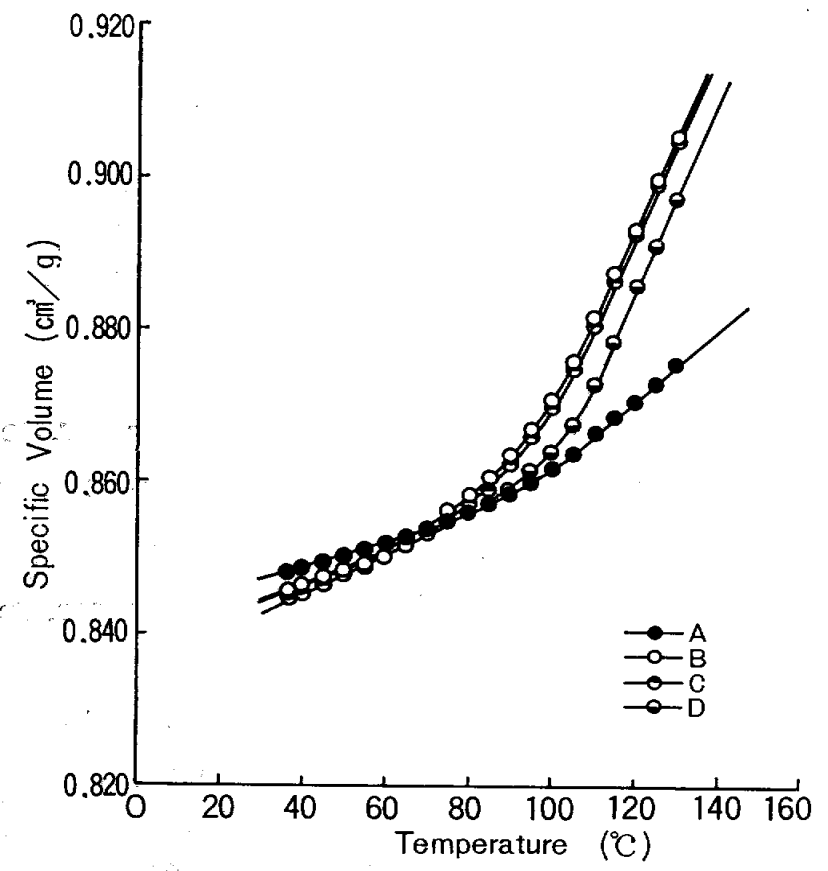

Fig. 10 Temperature Dependence of Specific Volume of SpecimenA, B, C and D

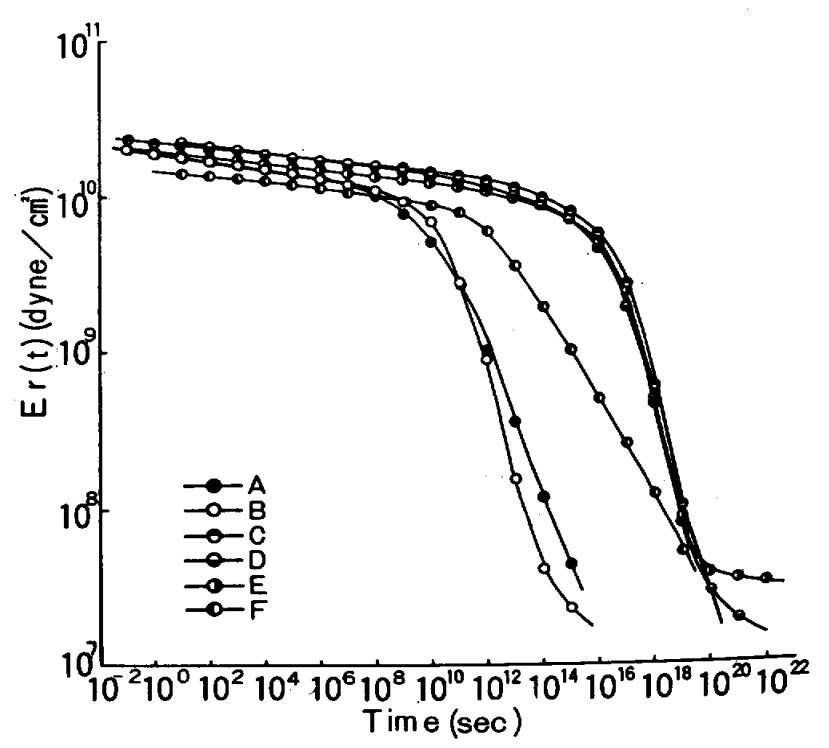

Fig. 11 Master Curve of Specimens A, B, C, D, $\mathrm{E}$ and $\mathrm{F}$

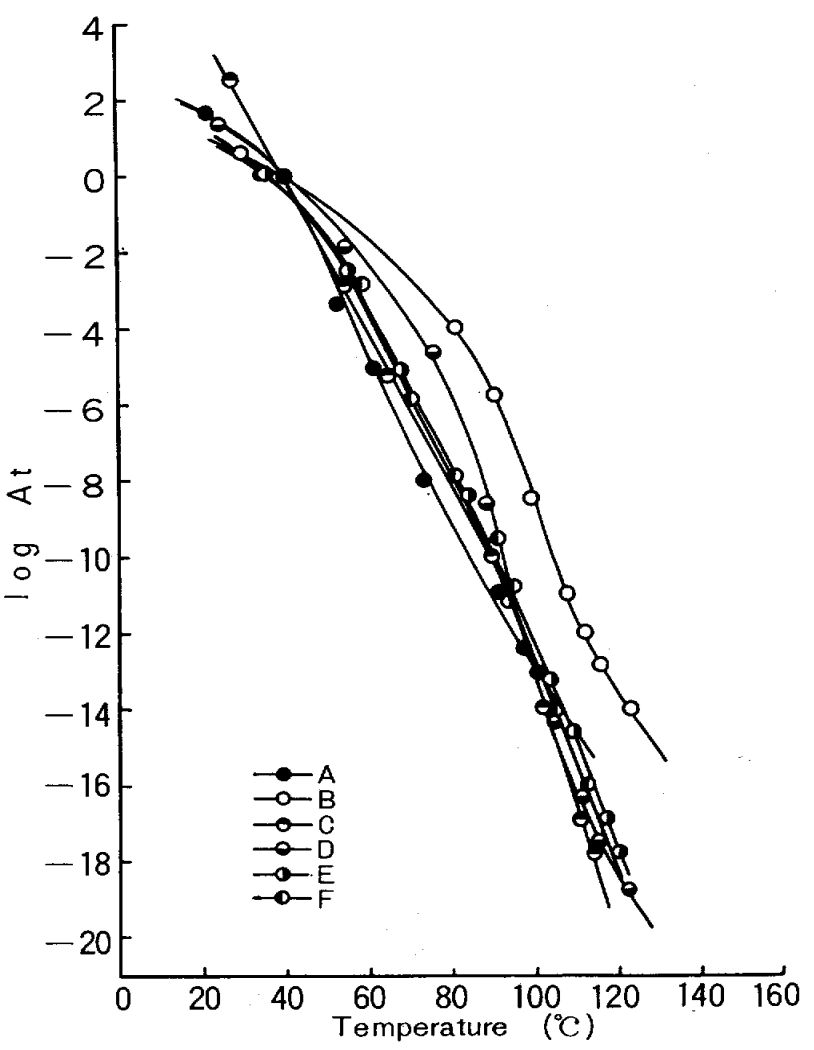

Fig. 12 Shift Factor vs Temperature Curve 


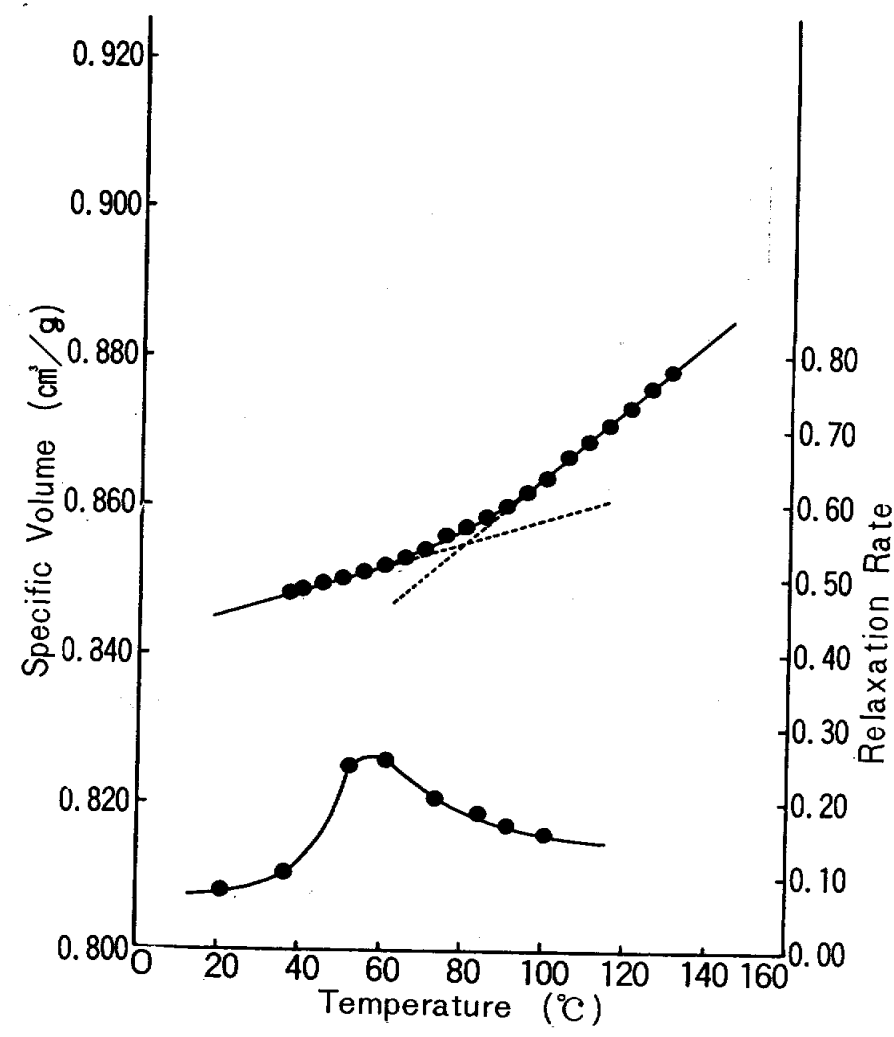

Fig. 13 Temperature Dependence of Specific Volume and Relaxation Rate of Specimen A

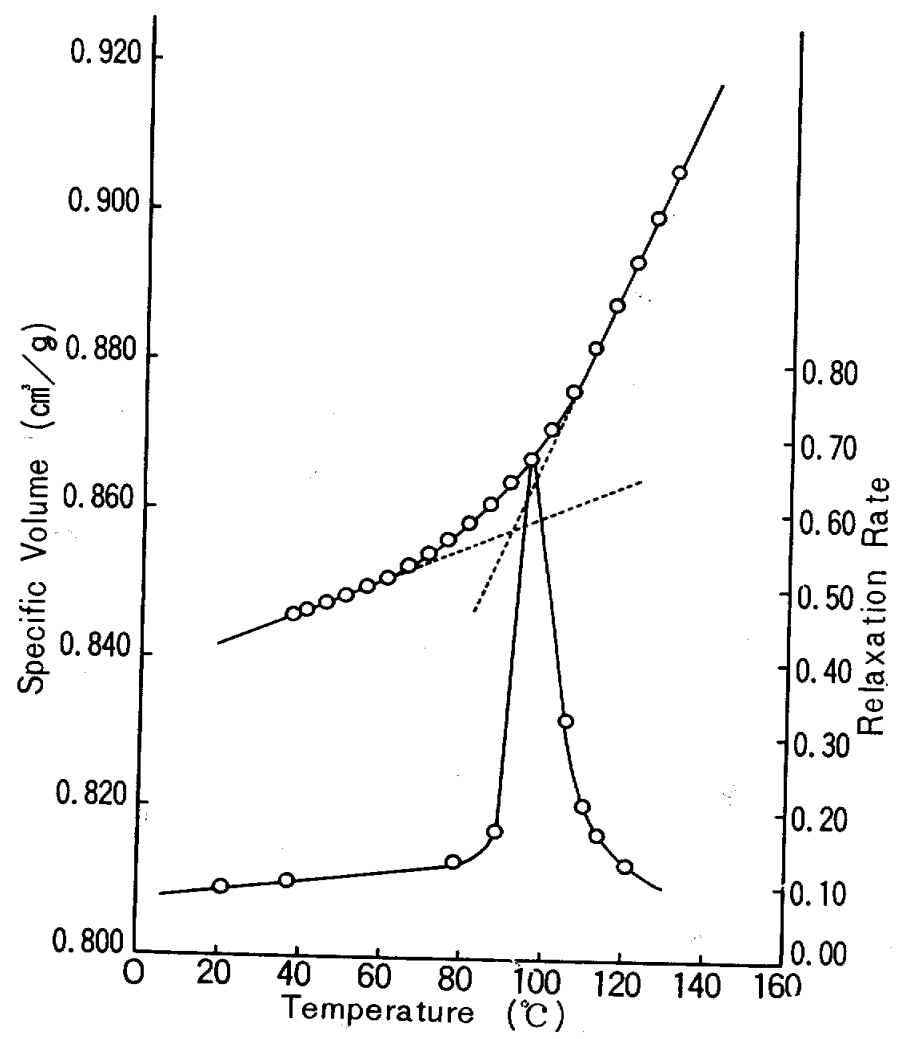

Fig. 14 Temperature Dependence of Specific Volume and Relaxation Rate of Specimen B

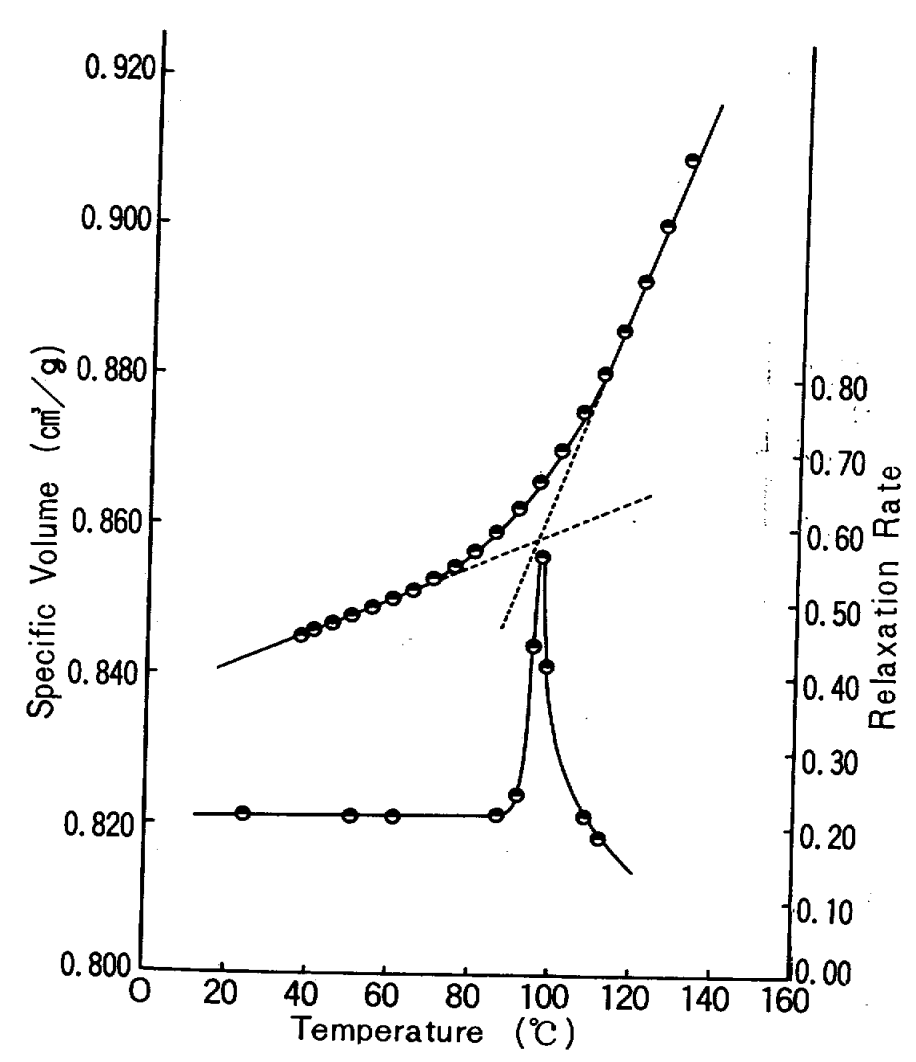

Fig. 15 Temperature Dependence of Specific Volume and Relation Rate of Specimen C

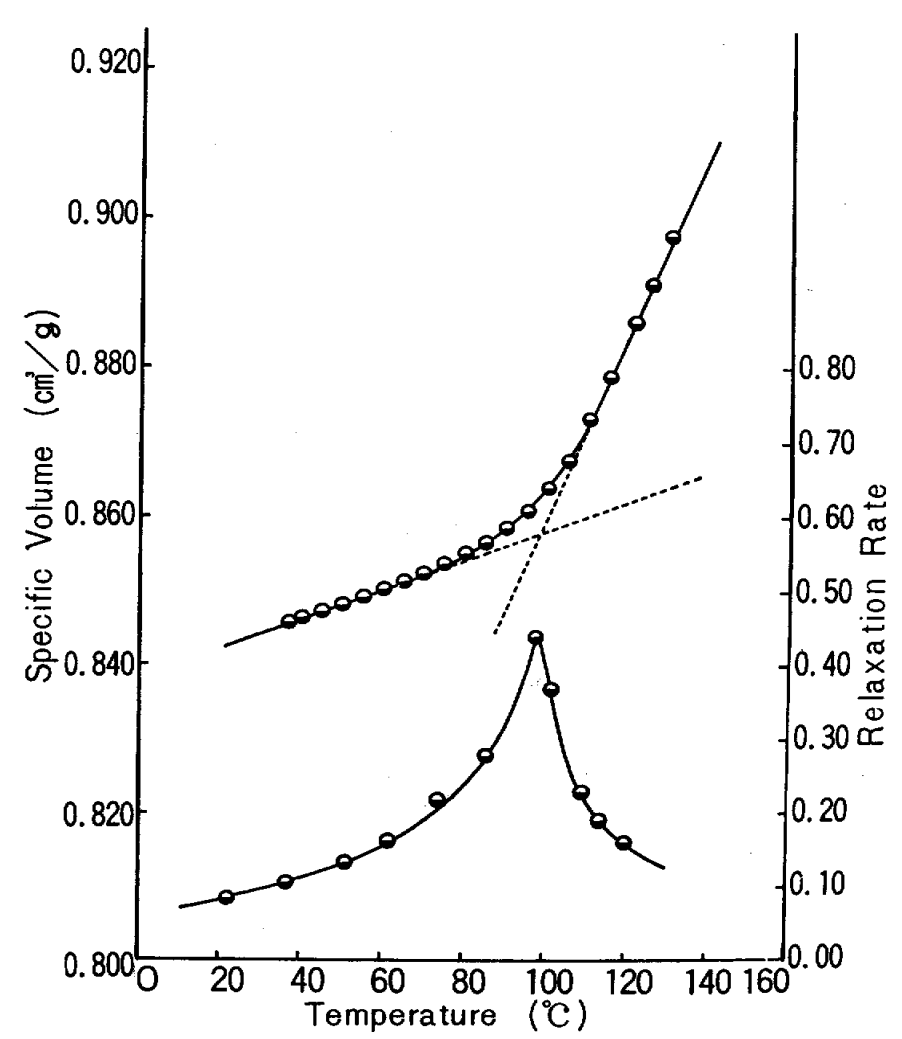

Fig. 16 Temperature Dependence of Specific Volume and Relaxation Rate of Specimen D 


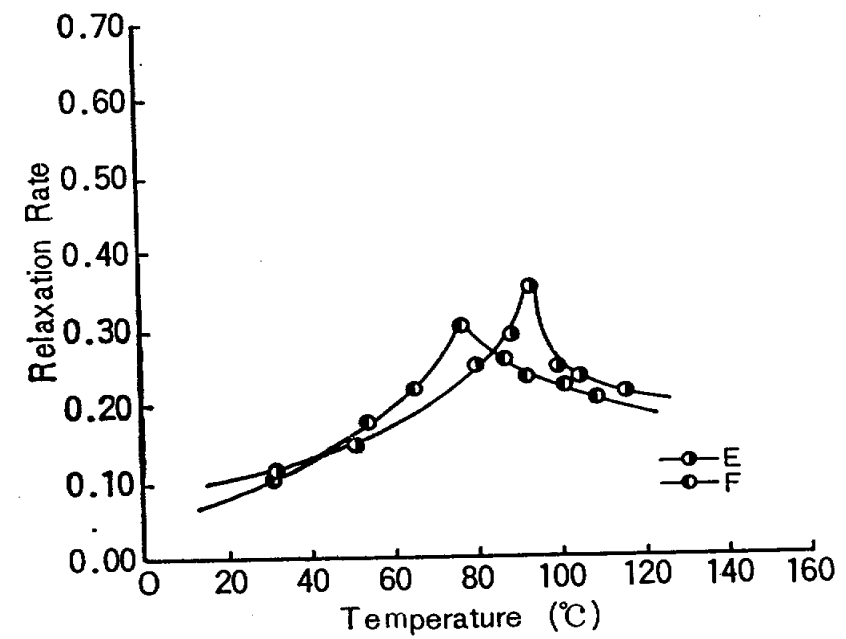

Fig. 17 Relaxation Rate of Specimen E and F

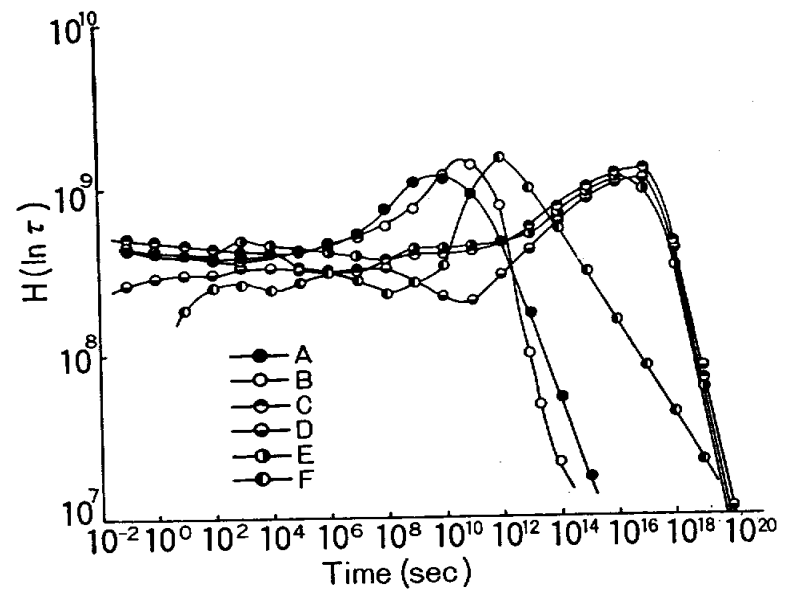

Fig. 19 Relaxation Time Spectra of Specimen A, B, C, D, E and F

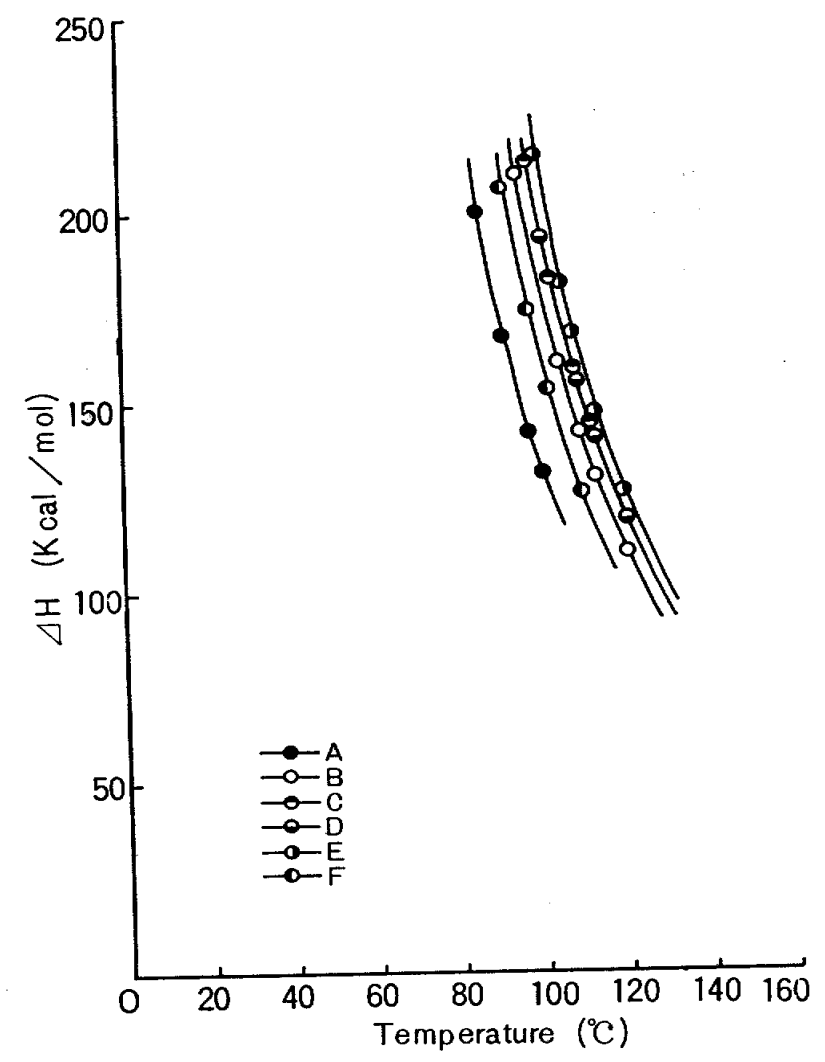

Fig. 18 Apparent Activation Energy on Stress Relaxation Process of Specimens A, B, C, D, $\mathbf{E}$ and $\mathbf{F}$ 
FUNDAMENTAL STUDIES ON VISCOELASTICITY OF POLYMETHYL METHACRYLATE - 459 POLYMERIZED BY MONOMER-POLYMER TECHNIQUE

Table 1 Molding Technique

\begin{tabular}{|c|c|c|c|}
\hline specimen & material & monomer-polymer ratio & technique \\
\hline A & polymer & 0 & heating to $180^{\circ} \mathrm{C}$ and pressing \\
\hline $\mathbf{B}$ & monomer-polymer & $\frac{1}{2}-$ & dental curing technique \\
\hline $\mathrm{C}$ & $\begin{array}{l}\text { monomer-polymer (crosslin- } \\
\text { ked by D. V.B.) }\end{array}$ & $\frac{1}{2}$ & dental curing technique \\
\hline $\mathrm{D}$ & $\begin{array}{l}\text { monomer-polymer (crosslin- } \\
\text { ked by E. D. M. A.) }\end{array}$ & $\frac{1}{2}$ & dental curing technique \\
\hline $\mathbf{E}$ & $\begin{array}{l}\text { monomer - polymer (commer- } \\
\text { cial dental resin) }\end{array}$ & $\frac{1}{2}$ & dental curing technique \\
\hline $\mathbf{F}$ & organic glass & 0 & heating to $180^{\circ} \mathrm{C}$ and pressing \\
\hline
\end{tabular}

Table 2 Temperature Dependence of Stress Relaxation Modulus of Specimen A

\begin{tabular}{|c|c|c|c|c|c|c|c|c|c|c|c|}
\hline \multirow{2}{*}{$\begin{array}{l}\text { Time } \\
(\mathrm{sec})\end{array}$} & \multicolumn{11}{|c|}{ Measured Stress Relaxation Modulus $\mathrm{E}_{\mathrm{r}}(\mathrm{t})$} \\
\hline & $21.0^{\circ} \mathrm{C}$ & $37.0^{\circ} \mathrm{C}$ & $52.5^{\circ} \mathrm{C}$ & $61.0^{\circ} \mathrm{C}$ & 74. $2^{\circ} \mathrm{C}$ & $81.5^{\circ} \mathrm{C}$ & $85.5^{\circ} \mathrm{C}$ & $91.0^{\circ} \mathrm{C}$ & $97.0^{\circ} \mathrm{C}$ & $100.0^{\circ} \mathrm{C}$ & $106.0^{\circ} \mathrm{C}$ \\
\hline 5 & $|1.81 \times 10|$ & $1.71 \times 10$ & $1.48 \times 10$ & $1.34 \times 10$ & $1.12 \times 10$ & $017.60 \times 10^{9}$ & $4.85 \times 10^{9}$ & $1.68 \times 10^{9}$ & $3.11 \times 10^{8}$ & $1.64 \times 10^{8}$ & $6.85 \times 10^{7}$ \\
\hline 10 & 1. 78 & 1. 68 & 1. 46 & 1. 30 & 1.09 & 6.89 & 3. 89 & 1. 38 & 2. 39 & 1. 30 & 5.35 \\
\hline 15 & 1.76 & 1.67 & 1. 45 & 1. 29 & 1.08 & 6.50 & 3. 52 & 1.23 & 2. $03^{\circ}$ & 1. 11 & 4. 49 \\
\hline 25 & 1.73 & 1.65 & 1. 43 & 1. 27 & 1.06 & 5.90 & 3. 01 & 1.05 & 1. 56 & $7.90 \times 10^{7}$ & 2. 14 \\
\hline 40 & 1.71 & 1.63 & 1. 41 & 1. 24 & 1.04 & 5. 45 & 2. 65 & $9.26 \times 10^{8}$ & 1.25 & 6.06 & $8.56 \times 10^{6}$ \\
\hline 60 & 1.70 & 1.62 & 1. 38 & 1. 22 & 1.03 & 5.03 & 2. 37 & 8. 36 & 1.14 & 5. 27 & \\
\hline 100 & 1.67 & 1.60 & 1. 35 & 1. 19 & 1.01 & 4.52 & 2.08 & 7. 47 & $8.70 \times 10$ & 4. 74 & \\
\hline 150 & 1.65 & 1.59 & 1. 33 & 1.16 & $9.88 \times 10$ & 4.16 & 1.89 & 6.57 & 7.97 & 4. 22 & \\
\hline 250 & 1.64 & 1. 57 & 1. 33 & 1. 14 & 9.68 & 3. 69 & 1. 63 & 5.68 & 6.81 & 3. 16 & \\
\hline 400 & 1.61 & 1.55 & 1.31 & 1. 12 & 9.51 & 3. 29 & 1. 42 & 5.07 & 6.05 & & \\
\hline 600 & 1.60 & 1.53 & 1. 27 & 1. I & 9.22 & 2.93 & 1.27 & 4. 77 & 4. 92 & & \\
\hline 1000 & 1.57 & 1.52 & 1. 27 & 1.05 & 8.95 & 2.53 & 1.08 & 4. 71 & 3.03 & & \\
\hline 1500 & 1.55 & 1.50 & 1. 24 & 1. OI & 8.60 & 2. 32 & 1.02 & 4. 71 & 2. 27 & & \\
\hline 2500 & 1.53 & 1. 49 & 1. 20 & $9.72 \times 10^{8}$ & 7.84 & 2.01 & & & & & \\
\hline 4000 & 1.51 & 1. 45 & 1. 18 & 9.04 & 7.50 & 1. 75 & & & & & \\
\hline 6000 & 1. 48 & 1. 44 & 1. 14 & 8.51 & 7. 19 & 1.70 & & & & & \\
\hline
\end{tabular}




\section{- 460 - FUNDAMENTAL STUDIES ON VISCOELASTICITY OF POLYMETHYL METHACRYLATE POLYMERIZED BY MONOMER-POLYMER TECHNIQUE}

Table 3 Temperature Dependence of Stress Relaxation Modulus of Specimen B

\begin{tabular}{|c|c|c|c|c|c|c|c|c|c|c|}
\hline \multirow{2}{*}{$\begin{array}{l}\text { Time } \\
\text { (sec) }\end{array}$} & \multicolumn{10}{|c|}{ Measured Stress Relaxation Modulus } \\
\hline & $20.5^{\circ} \mathrm{C}$ & $37.0^{\circ} \mathrm{C}$ & $78.0^{\circ} \mathrm{C}$ & $87.5^{\circ} \mathrm{C}$ & $95.5^{\circ} \mathrm{C}$ & $98.5^{\circ} \mathrm{C}$ & $104.5^{\circ} \mathrm{C}$ & $109.0^{\circ} \mathrm{C}$ & $112.5^{\circ} \mathrm{C}$ & $120.0^{\circ} \mathrm{C}$ \\
\hline 5 & $1.94 \times 10^{10}$ & $1.71 \times 10^{10}$ & $1.60 \times 10^{10}$ & 1. $43 \times 10$ & $1.01 \times 10^{10}$ & $8.06 \times 10^{9}$ & $1.70 \times 10^{9}$ & $4.19 \times 10^{8}$ & $9.31 \times 10^{7}$ & 3. $17 \times 10^{7}$ \\
\hline 10 & 1.91 & 1.68 & 1.57 & 1. 40 & 9. $35 \times 10^{9}$ & 7. 46 & 1. 19 & 2.07 & 5.94 & 2.90 \\
\hline 15 & 1.90 & 1.67 & 1.55 & 1. 37 & 8.86 & 7.04 & $9.39 \times 10^{8}$ & 1.50 & 4. 98 & 2.76 \\
\hline 25 & 1.87 & 1.66 & 1. 52 & 1. 34 & 8.25 & 6.52 & 6.06 & 1.01 & 4. 14 & 2. 62 \\
\hline 40 & 1.86 & 1.64 & 1.50 & 1. 31 & 7.59 & 5.99 & 4.08 & $6.88 \times 10^{7}$ & 3.68 & 2. 48 \\
\hline 60 & 1.83 & 1.63 & 1. 48 & 1. 28 & 7. 03 & 5.56 & 2.93 & 6.07 & 3. 21 & 2.35 \\
\hline 100 & 1.80 & 1. 61 & 1.45 & 1. 26 & 6.27 & 4.84 & 2. 11 & 5. 26 & 2.88 & 2.07 \\
\hline 150 & 1. 79 & 1. 59 & 1. 43 & 1. 23 & 5.63 & 4. 34 & 1. 63 & 4. 45 & 2.72 & \\
\hline 250 & 1. 77 & 1. 56 & 1. 40 & 1. 20 & 4.73 & 3.61 & 1.30 & 4.05 & & \\
\hline 400 & 1.75 & 1. 54 & 1. 36 & 1. 17 & 3. 95 & 3. 01 & 1.06 & 3.64 & & \\
\hline 600 & 1.73 & 1.52 & 1. 34 & 1. 12 & 3.26 & 2. 51 & & & & \\
\hline 1000 & 1.71 & 1. 52 & 1.32 & 1. 06 & 2. 46 & 1.86 & & & & \\
\hline 1500 & 1.69 & 1. 50 & 1. 28 & 1. 01 & 1.91 & 1. 48 & & & & \\
\hline 2500 & 1. 67 & 1. 48 & 1. 23 & 9. $30 \times 10^{9}$ & 1.32 & 1.06 & & & & \\
\hline 4000 & 1. 67 & 1. 46 & 1. 19 & 8.89 & 1.09 & 8. $46 \times 10^{8}$ & & & & \\
\hline 6000 & 1.64 & 1. 45 & 1. 15 & 8.59 & & & & & & \\
\hline
\end{tabular}

Table 4 Temperature Dependence of Stress Relaxation Modulus of Specimen C

\begin{tabular}{|c|c|c|c|c|c|c|c|c|c|c|}
\hline \multirow{2}{*}{$\begin{array}{l}\text { Time } \\
\text { (sec) }\end{array}$} & \multicolumn{10}{|c|}{ Measured Stress Relaxation Modulus } \\
\hline & $24.5^{\circ} \mathrm{C}$ & $37.0^{\circ} \mathrm{C}$ & $51.0^{\circ} \mathrm{C}$ & $61.5^{\circ} \mathrm{C}$ & $87.0^{\circ} \mathrm{C}$ & $91.5^{\circ} \mathrm{C}$ & $98.0^{\circ} \mathrm{C}$ & 103. $0^{\circ} \mathrm{C}$ & $108.0^{\circ} \mathrm{C}$ & $111.5^{\circ} \mathrm{C}$ \\
\hline 5 & $2.38 \times 10^{10}$ & $2.11 \times 10^{10}$ & $1.97 \times 10^{10}$ & $1.85 \times 10^{10}$ & $1.56 \times 10^{10}$ & $1.44 \times 10^{10}$ & $9.90 \times 10^{9}$ & 6. $12 \times 10^{9}$ & 1. $33 \times 10^{9}$ & $3.56 \times 10^{8}$ \\
\hline 10 & 2. 35 & 2. 08 & 1. 95 & 1. 82 & 1.53 & 1. 40 & 9.23 & 5. 69 & 8.58 & 2. 12 \\
\hline 15 & 2. 32 & 2.06 & 1.93 & 1. 80 & 1. 51 & 1,38 & 8. 78 & 5. 12 & 6.62 & 1. 46 \\
\hline 25 & 2. 30 & 2.04 & 1.92 & 1. 79 & 1. 48 & 1. 34 & 8. 18 & 4. 43 & 4. 36 & 9. $44 \times 10^{7}$ \\
\hline 40 & 2. 28 & 2.03 & 1. 91 & 1. 77 & 1. 46 & 1. 31 & 7.63 & 3.85 & 3. 10 & 6.83 \\
\hline 60 & 2. 26 & 2.02 & 1.89 & 1.76 & 1. 44 & 1.29 & 7.07 & 3.35 & 2.33 & 5.53 \\
\hline 100 & 2.25 & 2.01 & 1.87 & 1.75 & 1. 41 & 1. 26 & 6.45 & 2.66 & 1. 78 & 4.23 \\
\hline 150 & 2.22 & 1.99 & 1.85 & 1.75 & 1. 39 & 1. 22 & 5.79 & 2.19 & 1.55 & 3. 58 \\
\hline 250 & 2.19 & 1.97 & 1.84 & 1.75 & 1. 36 & 1. 19 & 4.88 & 1. 78 & 1. 24 & 3.58 \\
\hline 400 & 2. 18 & 1.95 & 1.83 & 1.72 & 1. 36 & 1.15 & 4. 23 & 1. 33 & & 3. 58 \\
\hline 600 & 2. 15 & 1.95 & 1.81 & 1.70 & 1. 34 & 1. 11 & 3.62 & 1. 16 & & \\
\hline 1000 & 2.11 & 1.94 & 1. 78 & 1.69 & 1.30 & 1.05 & 2.84 & 7. $22 \times 10^{\circ}$ & & \\
\hline 1500 & 2.07 & 1.92 & 1. 77 & 1.67 & 1. 28 & 1.01 & 2. 29 & 6.07 & & \\
\hline 2500 & 2.01 & 1.90 & 1. 74 & 1.65 & 1. 23 & $9.42 \times 10^{9}$ & 1. 59 & 3. 75 & & \\
\hline 4000 & 1.96 & 1. 87 & 1.71 & 1.63 & 1. 21 & 8.73 & 1.10 & & & \\
\hline 6000 & 1. 91 & & & & & 8.04 & & & & \\
\hline
\end{tabular}


FUNDAMENTAL STUDIES ON VISCOELASTICITY OF POLYMETHYL METHACRYLATE - 461 POLYMERIZED BY MONOMER-POLYMER TECHNIQUE

Table 5 Temperature Dependence of Stress Relaxation Modulus of Specimen D

\begin{tabular}{|c|c|c|c|c|c|c|c|c|c|c|c|}
\hline \multirow{2}{*}{$\begin{array}{l}\text { Time } \\
(\mathrm{sec})\end{array}$} & \multicolumn{11}{|c|}{ Measured Stress Relaxation Modulus $E_{r}(t)$} \\
\hline & $22.5^{\circ} \mathrm{C}$ & 37. $0^{\circ} \mathrm{C}$ & $51.6^{\circ} \mathrm{C}$ & 73. $5^{\circ} \mathrm{C}$ & $85.5^{\circ} \mathrm{C}$ & $94.5^{\circ} \mathrm{C}$ & $98.0^{\circ} \mathrm{C}$ & $\left|101.0^{\circ} \mathrm{C}\right|$ & $108.5^{\circ} \mathrm{C}$ & $112.5^{\circ} \mathrm{C}$ & $119.5^{\circ} \mathrm{C}$ \\
\hline 5 & $1.92 \times 10$ & $1.88 \times 10^{10}$ & $1.82 \times 10$ & $1.71 \times 10$ & 1. $44 \times 10^{10}$ & $1.36 \times 10$ & $1.06 \times 10$ & $7.92 \times 10^{9}$ & $2.45 \times 10^{9}$ & $4.23 \times 10^{8}$ & $4.93 \times 10^{7}$ \\
\hline 10 & 1.88 & 1.86 & 1. 80 & 1.69 & 1. 42 & 1. 30 & 1. 01 & 7. 25 & 1.68 & 2.33 & 3. 90 \\
\hline 15 & 1. 87 & 1.85 & 1. 78 & 1. 68 & 1. 41 & 1.27 & 9. $79 \times 10$ & 6.68 & 1.28 & 1.63 & 3. 49 \\
\hline 25 & 1.85 & 1.83 & 1.77 & 1. 66 & 1. 39 & 1. 24 & 9.36 & 6.07 & $8.91 \times 10^{8}$ & 1.08 & 3. 08 \\
\hline 40 & 1.83 & 1.82 & 1. 76 & 1.63 & 1. 38 & 1.23 & 8.97 & 5. 49 & 6. 32 & 8. $16 \times 10$ & 2. 88 \\
\hline 60 & 1.82 & 1.80 & 1.74 & 1.63 & 1. 36 & 1. 21 & 8.58 & 4.94 & 4.59 & 6. 42 & 2.67 \\
\hline 100 & 1. 80 & 1. 79 & 1. 72 & 1.61 & 1. 34 & 1. 19 & 8.08 & 4. 27 & 3. 04 & 4.92 & 2. 46 \\
\hline 150 & 1. 79 & 1. 78 & 1. 71 & 1.59 & 1. 33 & 1. 17 & 7.73 & 3. 71 & 2. 11 & 4. 37 & 2.37 \\
\hline 250 & 1. 76 & 1. 76 & 1.69 & 1. 57 & 1. 31 & 1. 15 & 7. 12 & 2.93 & 1.67 & 3.79 & 2.26 \\
\hline 400 & 1. 74 & 1. 74 & 1.67 & 1. 55 & 1. 30 & 1. 13 & 6.69 & 2. 37 & 9. $43 \times 10^{7}$ & 3. 50 & 2.26 . \\
\hline 600 & 1.73 & 1. 73 & 1.66 & 1.53 & 1. 30 & 1.09 & 6. 14 & 1.85 & 5.80 & 3. 21 & 2.26 \\
\hline 1000 & 1. 71 & 1. 70 & 1. 64 & 1. 52 & 1. 28 & 1.05 & 5. 37 & 1. 34 & & & \\
\hline 1500 & 1.67 & 1. 70 & 1.62 & 1. 50 & 1.26 & 1.01 & 4.68 & $8.69 \times 10^{8}$ & & & \\
\hline 2500 & 1.63 & 1.67 & 1.61 & 1. 49 & 1.23 & $9.57 \times 10^{9}$ & 3.90 & & & & \\
\hline 4000 & 1.61 & 1.64 & 1.60 & 1. 48 & 1.22 & 8.92 & 3. 04 & & & & \\
\hline 6000 & 1.60 & 1.62 & 1.58 & 1. 47 & 1.18 & & & & & & \\
\hline
\end{tabular}

Table 6 Temperature Dependence of Stress Relaxation Modulus of Specimen E

\begin{tabular}{|c|c|c|c|c|c|c|c|c|c|c|c|}
\hline \multirow{2}{*}{$\begin{array}{l}\text { Time } \\
\text { (sec) }\end{array}$} & \multicolumn{3}{|r|}{ Measured } & \multicolumn{3}{|c|}{ Stress Relaxation Modulus } & \multicolumn{3}{|c|}{ (dyne $\left./ \mathrm{cm}^{2}\right)$} & \multirow[b]{2}{*}{$116.5^{\circ} \mathrm{C}$} & \multirow[b]{2}{*}{$119.5^{\circ} \mathrm{C}$} \\
\hline & $32.5^{\circ} \mathrm{C}$ & $51.5^{\circ} \mathrm{C}$ & $64.0^{\circ} \mathrm{C}$ & $80.5^{\circ} \mathrm{C}$ & $89.5^{\circ} \mathrm{C}$ & $100.0^{\circ} \mathrm{C}$ & $105.5^{\circ} \mathrm{C}$ & $108.0^{\circ} \mathrm{C}$ & $113.0^{\circ} \mathrm{C}$ & & \\
\hline 5 & $2.28 \times 10^{10}$ & $2.07 \times 10^{10}$ & $1.90 \times 10^{10}$ & $1.63 \times 10^{10}$ & $\mid \begin{array}{r}1.32 \times 10 \\
0\end{array}$ & $\mid 1.06 \times 10^{10}$ & $7.86 \times 10^{9}$ & $4.96 \times 10^{9}$ & $1.32 \times 10^{9}$ & $3.00 \times 10^{8}$ & $9.35 \times 10^{7}$ \\
\hline 10 & 2.20 & 2.05 & 1.88 & 1. 58 & 1. 30 & 1.00 & 6.95 & 4. 22 & $8.70 \times 10^{8}$ & 1.95 & 6. 75 \\
\hline 15 & 2. 18 & 2.02 & 1.86 & 1.56 & 1. 25 & $|9.59 \times 10| 6$ & 6.54 & 3. 66 & 6.64 & 1. 47 & 5.65 \\
\hline 25 & 2.17 & 2.00 & 1.83 & 1.52 & 1. 22 & 9.06 & 5.92 & 3. 00 & 4. 38 & 1. 14 & 4. 79 \\
\hline 40 & 2. 15 & 1.98 & 1.82 & 1.50 & 1. 19 & 8. 53 & 5.32 & 2. 43 & 2.99 & $8.93 \times 10^{7}$ & 4.52 \\
\hline 60 & 2. 14 & 1.96 & 1.81 & 1. 49 & 1. 18 & 8. 13 & 4. 75 & 1.96 & 2. 09 & 7. 94 & 4. 24 \\
\hline 100 & 2. 11 & 1.94 & 1.79 & 1. 45 & 1. 15 & 7. 48 & 4. 01 & 1. 44 & 1.55 & 6. 98 & 4. 24 \\
\hline 150 & 2. 10 & 1.93 & 1.77 & 1. 42 & 1. 12 & 7. 00 & 3. 43 & 1. 12 & 1. 19 & 6. 64 & 4. 24 \\
\hline 250 & 2.08 & 1.90 & 1. 75 & 1.42 & 1.09 & 6.20 & 2.71 & 7. $64 \times 10^{8}$ & $9.72 \times 10^{7}$ & & 4. 24 \\
\hline 400 & 2.07 & 1.89 & 1. 73 & 1.38 & 1. 07 & 5. 58 & 2. 13 & 5. 25 & 8.81 & & 4. 24 \\
\hline 600 & 2.04 & 1. 88 & 1.73 & 1.36 & 1. 04 & 4. 85 & 1. 46 & 4. 10 & 7. 90 & & 4.24 \\
\hline 1000 & 2.01 & 1.86 & 1.69 & 1. 32 & $9.84 \times 10^{9}$ & 4. 15 & 1.22 & 3. 42 & 7.27 & & 4. 24 \\
\hline 1500 & 2.00 & 1.86 & 1.69 & 1. 31 & 9.57 & 3. 46 & $8.69 \times 10^{8}$ & 2.94 & 6.99 & & \\
\hline 2500 & 1.98 & 1.83 & 1.66 & 1. 28 & 9.07 & 2. 74 & 6.18 & & 6.69 & & \\
\hline 4000 & 1.97 & 1.83 & 1.63 & 1.25 & 8.65 & 2.09 & 4. 73 & & 6. 39 & & \\
\hline 6000 & & 1.82 & 1.63 & 1. 24 & 8.23 & 1. 73 & 3. 50 & & & & \\
\hline
\end{tabular}




\section{- 462 - FUNDAMENTAL STUDIES ON VISCOELASTICITY OF POLYMETHYL METHACRYLATE POLYMERIZED BY MONOMER-POLYMER TECHNIQUE}

Table 7 Temperature Dependence of Stress Relaxation Modulus of Specimen F

\begin{tabular}{|c|c|c|c|c|c|c|c|c|c|}
\hline \multirow{2}{*}{$\begin{array}{l}\text { Time } \\
(\mathrm{sec})\end{array}$} & \multicolumn{9}{|c|}{ Measured Stress Relaxation Modulus $E_{r}(t)$} \\
\hline & $32.0^{\circ} \mathrm{C}$ & $54.7^{\circ} \mathrm{C}$ & $65.8^{\circ} \mathrm{C}$ & $77.3^{\circ} \mathrm{C}$ & 87. $7^{\circ} \mathrm{C}$ & $92.0^{\circ} \mathrm{C}$ & $97.5^{\circ} \mathrm{C}$ & $102.0^{\circ} \mathrm{C}$ & $109.5^{\circ} \mathrm{C}$ \\
\hline 5 & 1. $41 \times 10^{10}$ & 1. $34 \times 10^{10}$ & 1. $18 \times 10^{10}$ & 1. $13 \times 10^{10}$ & $1.07 \times 10^{10}$ & 8. $17 \times 10^{9}$ & $2.26 \times 10^{9}$ & 1. $44 \times 10^{9}$ & 3. $83 \times 10^{8}$ \\
\hline 10 & 1.40 & 1.33 & 1. 16 & 1. 11 & 1.03 & 7. 49 & 1.91 & 1. 16 & 3. 14 \\
\hline 15 & 1. 38 & 1. 31 & 1. 15 & 1.09 & 1.01 & 6.97 & 1.70 & 1.01 & 2.74 \\
\hline 25 & 1.37 & 1.30 & 1. 14 & 1.07 & 9. $58 \times 10^{9}$ & 6. 28 & 1.47 & 8. $54 \times 10^{8}$ & 2. 34 \\
\hline 40 & 1.36 & 1.29 & 1. 13 & 1.06 & 9.06 & 5. 74 & 1. 30 & 7.51 & 1. 11 \\
\hline 60 & 1. 34 & 1.28 & 1.13 & 1.05 & 8.75 & 5. 20 & 1.17 & 6.62 & 1.84 \\
\hline 100 & 1. 33 & 1.27 & 1. 12 & 1.04 & 8.23 & 4.55 & 1.01 & 5.07 & 1.58 \\
\hline 150 & 1. 32 & 1.26 & 1. 11 & 1.02 & 7. 76 & 4.15 & $9.06 \times 10^{8}$ & 5.09 & 1.43 \\
\hline 250 & 1. 31 & 1.24 & 1.09 & $9.95 \times 10^{9}$ & 7. 17 & 3.64 & 7.63 & 4. 40 & 1. 14 \\
\hline 400 & 1. 30 & 1.23 & 1.09 & 9.69 & 6.65 & 3. 20 & 6.90 & 3. 70 & $9.52 \times 10^{7}$ \\
\hline 600 & 1.29 & 1.22 & 1.07 & 9.59 & 6.16 & 2.92 & 6. 17 & 3. 30 & 8. 25 \\
\hline 1000 & 1.29 & 1.21 & 1.06 & 9. 19 & 5. 56 & 2. 50 & 5.53 & 2.84 & 6. 29 \\
\hline 1500 & 1. 28 & 1. 19 & 1.06 & 8.89 & 5.07 & 2. 26 & 4.91 & 2. 45 & 5.67 \\
\hline 2500 & 1.27 & 1. 17 & 1. 04 & 8. 45 & 4.57 & 2.04 & 4. 41 & 1.95 & 4. 41 \\
\hline 4000 & 1. 27 & 1. 16 & 1.03 & 8. 16 & 4. 01 & 1.81 & 4.03 & & 3. 15 \\
\hline 6000 & 1.27 & 1.15 & 1.02 & 7. 78 & 3.53 & 1. 72 & 3.65 & & \\
\hline
\end{tabular}

Table 8 Temperature Dependence of Specific Volume of Specimens A, B, C and D

\begin{tabular}{c|c|c|c|c}
\hline \hline \multirow{2}{*}{ Temperature ( $\left.{ }^{\circ} \mathbf{C}\right)$} & \multicolumn{3}{|c|}{ Specific Volume $\left(\mathbf{c m}^{3} / \mathbf{g}\right)$} & D \\
\cline { 2 - 5 } & A & B & C & 0.8459 \\
47.0 & 0.8480 & 0.8459 & 0.8452 & 0.8464 \\
45.0 & 0.8485 & 0.8465 & 0.8456 & 0.8472 \\
50.0 & 0.8493 & 0.8474 & 0.8465 & 0.8481 \\
55.0 & 0.8501 & 0.8484 & 0.8475 & 0.8492 \\
60.0 & 0.8510 & 0.8496 & 0.8487 & 0.8502 \\
65.0 & 0.8520 & 0.8509 & 0.8499 & 0.8513 \\
70.0 & 0.8529 & 0.8525 & 0.8512 & 0.8524 \\
75.0 & 0.8540 & 0.8542 & 0.8528 & 0.8537 \\
80.0 & 0.8550 & 0.8561 & 0.8544 & 0.8550 \\
85.0 & 0.8560 & 0.8582 & 0.8565 & 0.8566 \\
90.0 & 0.8571 & 0.8607 & 0.8591 & 0.8585 \\
95.0 & 0.8584 & 0.8636 & 0.8624 & 0.8608 \\
100.0 & 0.8598 & 0.8668 & 0.8659 & 0.8639 \\
105.0 & 0.8617 & 0.8708 & 0.8701 & 0.8674 \\
110.0 & 0.8637 & 0.8759 & 0.8753 & 0.8730 \\
115.0 & 0.8666 & 0.8818 & 0.8805 & 0.8787 \\
120.0 & 0.8685 & 0.8876 & 0.8862 & 0.8861 \\
125.0 & 0.8707 & 0.8933 & 0.8929 & 0.8911 \\
130.0 & 0.8731 & 0.8991 & 0.9003 & 0.8975 \\
\hline
\end{tabular}


FUNDAMENTAL STUDIES ON VISCOELASTICITY OF POLYMETHYL METHACRYLATE - 463 POLYMERIZED BY MONOMER-POLYMER TECHNIQUE

Table 9 Grass Transition Temperature obtained by Specific Volume Measurement and Stress Relaxation Measurement

\begin{tabular}{|c|c|c|}
\hline Specimen & \begin{tabular}{|l|} 
\\
Specific Volume \\
Measurement
\end{tabular} & $\begin{array}{l}\text { Stress Relaxation } \\
\text { Measurement }\end{array}$ \\
\hline A & $80^{\circ} \mathrm{C}$ & $61^{\circ} \mathrm{C}$ \\
\hline B & 92 & 95 \\
\hline $\mathrm{C}$ & 95 & 97 \\
\hline $\mathrm{D}$ & 98 & 98 \\
\hline $\mathbf{E}$ & - & 94 \\
\hline $\mathbf{F}$ & - & 77 \\
\hline
\end{tabular}

Table 10 Temperature Dependence of $\log a_{\mathrm{T}}$ and $\left\{\frac{\mathrm{d}\left(\log a_{\mathrm{T}}\right)}{\mathrm{dT}}\right\}$ of Specimen A

\begin{tabular}{c|c|c}
\hline Temperature $\left({ }^{\circ} \mathrm{C}\right)$ & $\log a_{\mathrm{T}}$ & $\left\{\frac{\mathrm{d}\left(\log a_{\mathrm{T}}\right)}{\mathrm{dT}}\right\}$ \\
\hline 21.0 & -1.6839 & 0.080 \\
37.0 & 0 & 0.150 \\
52.5 & 3.4314 & 0.250 \\
61.0 & 5.1216 & 0.260 \\
73.0 & 8.1747 & 0.205 \\
91.0 & 10.9071 & 0.171 \\
97.0 & 12.5092 & 0.156 \\
100.0 & 13.1427 & 0.158 \\
\hline
\end{tabular}

Table 11 Temperature Dependence of $\log a_{\mathrm{T}}$ and $\left\{\frac{\mathrm{d}\left(\log a_{\mathrm{T}}\right)}{\mathrm{dT}}\right\}$ of Specimen B

\begin{tabular}{c|c|c}
\hline \hline Temperature $\left({ }^{\circ} \mathrm{C}\right)$ & $\log a_{\mathrm{T}}$ & $\left\{\frac{\mathrm{d}\left(\log a_{\mathrm{T}}\right)}{\mathrm{dT}}\right\}$ \\
\hline 20.5 & -2.7782 & 0.089 \\
37.0 & 0 & 0.098 \\
78.0 & 4.0000 & 0.127 \\
87.5 & 5.8573 & 0.162 \\
95.5 & 8.5201 & 0.667 \\
104.5 & 10.9749 & 0.320 \\
109.0 & 11.9877 & 0.205 \\
112.5 & 12.8450 & 0.167 \\
120.0 & 13.9623 & 0.125 \\
\hline
\end{tabular}

Table 12 Temperature Dependence of $\log a_{\mathrm{T}}$ and $\left\{\frac{\mathrm{d}\left(\log a_{\mathrm{T}}\right)}{\mathrm{dT}}\right\}$ of Specimen $\mathrm{C}$

\begin{tabular}{c|c|c}
\hline \hline Temperature $\left({ }^{\circ} \mathrm{C}\right)$ & $\log a_{\mathrm{T}}$ & $\left\{\frac{\mathrm{d}\left(\log a_{\mathrm{T}}\right)}{\mathrm{dT}}\right\}$ \\
\hline 24.5 & -2.6212 & 0.210 \\
37.0 & 0 & 0.210 \\
51.0 & 3.0000 & 0.210 \\
61.5 & 5.3385 & 0.210 \\
87.0 & 10.1773 & 0.213 \\
91.5 & 11.4783 & 0.240 \\
98.0 & 14.1773 & 0.414 \\
108.0 & 16.9555 & 0.213 \\
111.5 & 17.8218 & 0.186 \\
\hline
\end{tabular}

TaBle 13 Temperature Dependence of $\log a_{\mathrm{T}}$ and $\left\{\frac{\mathrm{d}\left(\log a_{\mathrm{T}}\right)}{\mathrm{dT}}\right\}$ of Specimen D

\begin{tabular}{c|c|c}
\hline Temperature $\left({ }^{\circ} \mathrm{C}\right)$ & $\log a_{\mathbf{T}}$ & $\left\{\frac{\mathrm{d}\left(\log a_{\mathbf{T}}\right)}{\mathrm{dT}}\right\}$ \\
\hline 22.5 & -1.3010 & 0.083 \\
37.0 & 0 & 0.105 \\
51.6 & 1.8921 & 0.133 \\
61.5 & 3.2900 & 0.160 \\
73.5 & 4.6879 & 0.217 \\
85.5 & 8.6879 & 0.275 \\
98.0 & 13.2320 & 0.436 \\
101.0 & 14.5333 & 0.367 \\
108.5 & 16.3395 & 0.229 \\
112.5 & 17.4948 & 0.191 \\
119.5 & 18.7893 & 0.160 \\
\hline
\end{tabular}

Table 14 Temperature Dependence of $\log a_{\mathrm{T}}$ and $\left\{\frac{\mathrm{d}\left(\log a_{\mathrm{T}}\right)}{\mathrm{dT}}\right\}$ of Specimen $\mathrm{E}$

\begin{tabular}{c|c|c}
\hline \hline Temperature $\left({ }^{\circ} \mathrm{C}\right)$ & $\log a_{\mathbf{T}}$ & $\left\{\frac{\mathrm{d}\left(\log a_{\mathbf{T}}\right)}{\mathrm{dT}}\right\}$ \\
\hline 32.5 & 0 & 0.113 \\
51.5 & 2.5682 & 0.145 \\
64.0 & 5.1364 & 0.195 \\
80.5 & 8.4374 & 0.250 \\
89.5 & 11.1534 & 0.288 \\
100.0 & 13.3237 & 0.244 \\
105.5 & 14.6591 & 0.233 \\
113.0 & 16.8946 & 0.229 \\
116.5 & 17.8084 & 0.214 \\
119.5 & 18.6279 & \\
\hline
\end{tabular}




\section{- 464 - FUNDAMENTAL STUDIES ON VISCOELASTICITY OF POLYMETHYL METHACRYLATE POLYMERIZED BY MONOMER-POLYMER TECHNIQUE}

Table 15 Temperature Dependence of $\log a_{\mathbf{T}}$ and $\left\{\frac{\mathrm{d}\left(\log a_{\mathrm{T}}\right)}{\mathrm{dT}}\right\}$ of Specimen $\mathrm{F}$

\begin{tabular}{c|c|c}
\hline Temperature $\left({ }^{\circ} \mathrm{C}\right)$ & $\log a_{\mathrm{T}}$ & $\left\{\frac{\mathrm{d}\left(\log a_{\mathbf{T}}\right)}{\mathrm{dT}}\right\}$ \\
\hline 32.0 & 0 & 0.103 \\
54.7 & $2.892 \mathrm{l}$ & 0.175 \\
65.8 & 5.9820 & 0.217 \\
77.3 & 7.8851. & 0.300 \\
87.7 & 9.5135 & 0.256 \\
92.0 & 10.8500 & 0.233 \\
97.5 & 13.3271 & 0.233 \\
102.0 & 14.1053 & 0.225 \\
109.5 & 15.9596 & 0.206 \\
\hline
\end{tabular}

Table 16 Temperature Dependence of Apparent Activation energy on Stress Relaxation Process of Specimen A

\begin{tabular}{c|c|c}
\hline \hline Temperature $\left({ }^{\circ} \mathrm{C}\right)$ & $\mathrm{T}-\mathrm{Tg}\left({ }^{\circ} \mathrm{C}\right)$ & $\Delta \mathrm{H}(\mathrm{kcal} / \mathrm{mol})$ \\
\hline 85.5 & 0 & 199 \\
91.0 & 5.5 & 167 \\
97.0 & 11.5 & 142 \\
100.0 & 14.5 & 131 \\
\hline
\end{tabular}

Table 17 Temperature Dependence of Apparent Activation energy on Stress Relaxation Process of Specimen B

\begin{tabular}{c|c|c}
\hline \hline Temperature $\left({ }^{\circ} \mathrm{C}\right)$ & $\mathrm{T}-\mathrm{Tg}\left({ }^{\circ} \mathrm{C}\right)$ & $\Delta \mathrm{H}(\mathrm{kcal} / \mathrm{mol})$ \\
\hline 95.5 & 0 & 210 \\
104.5 & 9.0 & 160 \\
109.0 & 13.5 & 142 \\
112.5 & 17.0 & 130 \\
120.0 & 24.5 & 110 \\
\hline
\end{tabular}

Table 18 Temperature Dependence of Apparent Activation energy on Stress Relaxation Process of Specimen C

\begin{tabular}{c|c|c}
\hline \hline Temperature $\left({ }^{\circ} \mathrm{C}\right)$ & $\mathbf{T}-\mathbf{T g}\left({ }^{\circ} \mathbf{C}\right)$ & $\Delta \mathbf{H}(\mathbf{k c a l} / \mathbf{m o l})$ \\
\hline 98.0 & 0 & 213 \\
103.0 & 5.0 & 182 \\
108.0 & 10.0 & 158 \\
111.5 & 13.5 & 144 \\
\hline
\end{tabular}

Table 19 Temperature Dependence of Apparent Activation energy on Stress Relaxation Process of Specimen D

\begin{tabular}{c|c|c}
\hline \hline Temperature $\left({ }^{\circ} \mathrm{C}\right)$ & $\mathbf{T}-\mathbf{T g}\left({ }^{\circ} \mathrm{C}\right)$ & $\Delta \mathbf{H}(\mathbf{k c a l} / \mathbf{m o l})$ \\
\hline 98.0 & 0 & 213 \\
101.0 & 3.0 & 193 \\
108.5 & 10.5 & 155 \\
112.5 & 14.5 & 140 \\
119.5 & 21.5 & 119 \\
\hline
\end{tabular}

Table 20 Temperature Dependence of Apparent Activation energy on Stress Relaxation Process of Specimen E

\begin{tabular}{c|c|c}
\hline \hline Temperature $\left({ }^{\circ} \mathrm{C}\right)$ & $\mathrm{T}-\mathrm{Tg}\left({ }^{\circ} \mathrm{C}\right)$ & $\Delta \mathrm{H}(\mathrm{kcal} / \mathrm{mol})$ \\
\hline 100.0 & 0 & 215 \\
105.5 & 5.5 & 181 \\
108.0 & 8.0 & 168 \\
113.0 & 13.0 & 147 \\
119.5 & 19.5 & 126 \\
\hline
\end{tabular}

Table 21 Temperature Dependence of Apparent Activation energy on Stress Relaxation Process of Specimen F

\begin{tabular}{c|r|c}
\hline Temperature $\left({ }^{\circ} \mathbf{C}\right)$ & $\mathbf{T}-\mathrm{Tg}\left({ }^{\circ} \mathrm{C}\right)$ & $\Delta \mathrm{H}(\mathrm{kcal} / \mathbf{m o l})$ \\
\hline 92.0 & 0 & 206 \\
97.5 & 5.5 & $174, \%$ \\
102.0 & 10.0 & 153 \\
109.5 & 17.5 & 126 \\
\hline
\end{tabular}


FUNDAMENTAL STUDIES ON VISCOELASTICITY OF POLYMETHYL METHACRYLATE - 465 POLYMERIZED BY MONOMER-POLYMER TECHNIQUE

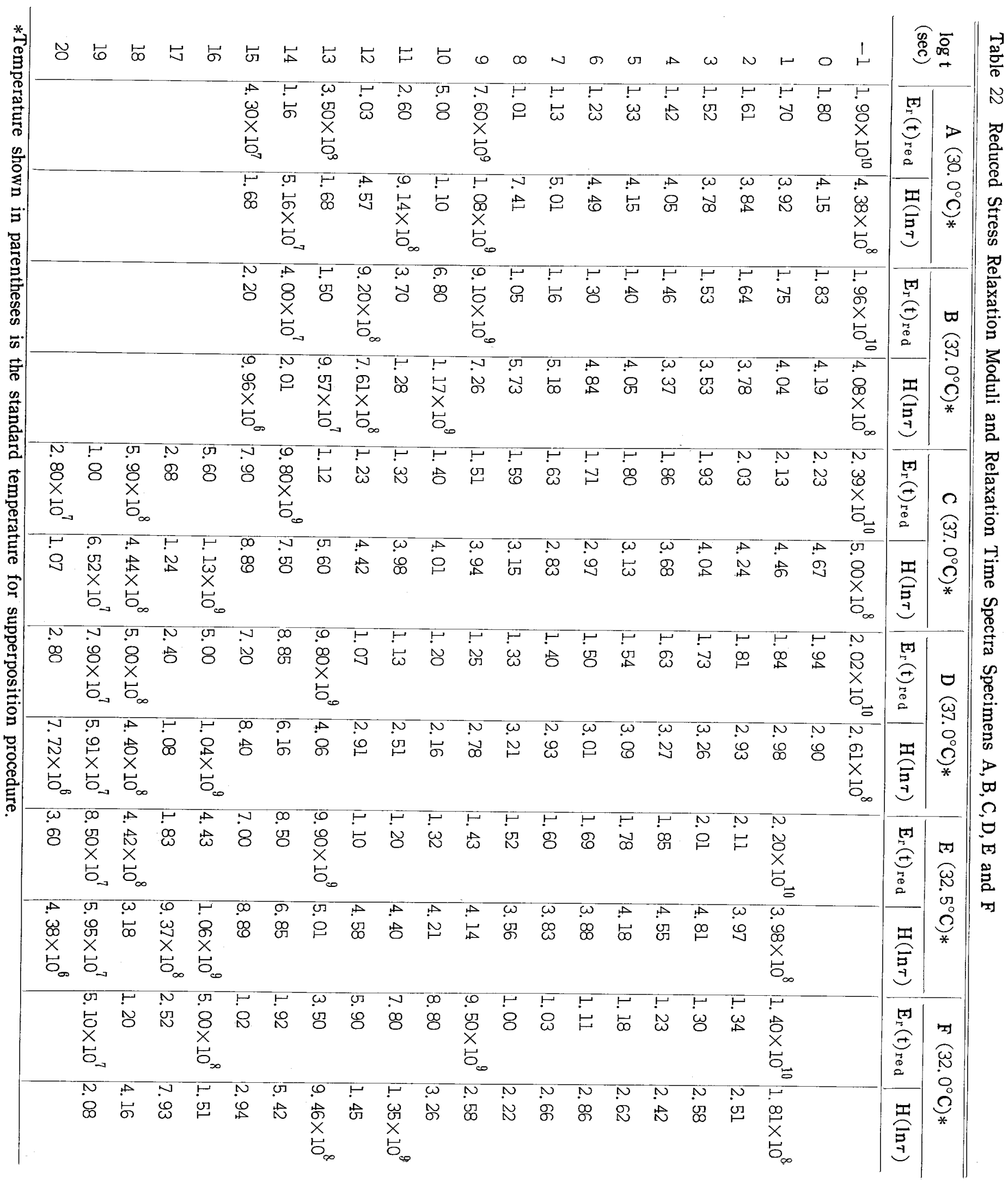

